\title{
Seasonal and interannual patterns of sediment- water nutrient and oxygen fluxes in Mobile Bay, Alabama (USA): regulating factors and ecological significance
}

\author{
Jean L. W. Cowan ${ }^{1, *}$, Jonathan R. Pennock ${ }^{2}$, Walter R. Boynton ${ }^{3}$ \\ ${ }^{1}$ University of South Alabama and ${ }^{2}$ The University of Alabama, Dauphin Island Sea Lab, PO Box 369-370, Dauphin Island, \\ Alabama 36528, USA \\ ${ }^{3}$ University of Maryland System, Center for Environmental and Estuarine Studies, Chesapeake Biological Laboratory, \\ PO Box 38, Solomons, Maryland 20688, USA
}

\begin{abstract}
Sediment oxygen and nutrient fluxes were measured monthly for 2 yr in Mobile Bay, Alabama, USA. Rates of sediment oxygen consumption $\left(0.1\right.$ to $\left.1.25 \mathrm{gO}_{2} \mathrm{~m}^{-2} \mathrm{~d}^{-1}\right)$, ammonium flux $\left(-22\right.$ to $\left.181 \mu \mathrm{mol} \mathrm{m} \mathrm{m}^{-2} \mathrm{~h}^{-1}\right)$, nitrate flux $\left(-14\right.$ to $\left.67 \mu \mathrm{mol} \mathrm{m} \mathrm{m}^{-2} \mathrm{~h}^{-1}\right)$, phosphate flux $\left(-2\right.$ to $\left.20.4 \mu \mathrm{mol} \mathrm{m}^{-2} \mathrm{~h}^{-1}\right)$. and dissolved silicate flux (-15 to $\left.342 \mu \mathrm{mol} \mathrm{m}^{-2} \mathrm{~h}^{-1}\right)$ were moderate to high compared to values for other estuaries. A step-wise regression analysis revealed that dissolved oxygen concentration and temperature in bottom-waters explained much of the variance in fluxes. This is presumably because of their influence on rates of microbial and physico-chemical processes. Organic matter availability was not found to be an important factor in regulating temporal (month to month) variability of fluxes, possibly because frequent resuspension of the sediments in this shallow system rendered indices of sediment organic matter nearly constant with time. However, warm season-averaged sediment nutrient releases were correlated with sediment chlorophyll a. This relationship in Mobile Bay is in strong agreement with similar relationships found in other estuarine systems, and suggests that the availability of labile organic matter ultimately regulates the maximum rate of nutrient release by the sediments. Annually averaged sediment fluxes supplied $36 \%$ of the nitrogen $(N)$ and $25 \%$ of the phosphorus $(P)$ required by phytoplankton in Mobile Bay. While this is not particularly high compared to other estuaries, monthly estimates show that the sediments can supply from 0 to $94 \%$ of the $N$, and 0 to $83 \%$ of the P required by phytoplankton. In addition, flux ratios show that $N$ and $P$ are released from sediments at $N: P$ ratios that rapidly switch from above (maximum 98) to below (minimum 1.2) that required for phytoplankton growth. This pattern is different from cooler temperate systems, where such switching is seasonally based.
\end{abstract}

KEY WORDS: Sediment-water fluxes Mobile Bay $\cdot$ Nutrient regeneration

\section{INTRODUCTION}

Benthic and pelagic processes are generally very tightly coupled in shallow estuarine environments, with organic matter produced in the water-column fueling sediment nutrient regeneration (Officer \& Ryther 1980, Nixon 1981, Jensen et al. 1990), which in turn sustains phytoplankton production (Davies 1975 ,

•E-mail: jwcowan@jaguar1.usouthal.edu
Boynton et al. 1980). Kemp et al. (1992) found that these relationships are especially important when water column depth is less than $5 \mathrm{~m}$, such as in Mobile Bay, Alabama, USA. It has been estimated that the sediments are the site of decomposition for up to $50 \%$ of the organic matter produced in the water-column (Nixon \& Pilson 1983), and that the resulting regenerated nutrients can provide 20 to $80 \%$ of the nitrogen and 10 to $80 \%$ of the phosphorus required by phytoplankton in estuaries (Fisher et al. 1982). 
Because of the demonstrated importance of nutrients regenerated by the sediments in sustaining water-column primary production, a great deal of effort has been focused on trying to understand what factors are important in regulating sediment-water exchanges of nutrients. These have been shown to include such variables as the supply and quality of organic material (Nixon 1981, Jensen et al. 1990), temperature (Hargrave 1969), the redox status of both the sediments and the overlying water via its effect on rates of nitrification and denitrification and chemical sorption/desorption processes (Patrick \& Khalid 1974, Seitzinger 1988. Kemp et al. 1990, Sundby et al. 1992). Overlying water nutrient concentrations are also potential regulators of fluxes because they may influence diffusion gradients and, thus, the direction of fluxes into or out of the sediments (Pomeroy et al. 1965, Boynton \& Kemp 1985). Finally, macroinfaunal activity (Henriksen et al. 1980, Bantê ct al. 1995) and the physical stability of the sediments may influence diffusion gradients, and so influence the magnitude and direction of fluxes (Sondergaard et al. 1992, Vidal 1994).

Some recent studies have shown that the rate of organic matter supply to the sediments is the factor that ultimately controls the potential magnitude of sediment nutrient fluxes (Kelly \& Nixon 1984, Jensen et al. 1990), and these authors have suggested that other factors are secondary in influence. Additionally, it appears that the relative influence of these secondary factors varies from region to region (e.g. Cowan \& Boynton 1996)

In this study, sediment-water nutrient and oxygen fluxes were measured monthly during a 2 yr period in Mobile Bay, concurrently with measurements of selected hydrographic, water-column, and sediment parameters. These data were then used to examine which of these parameters regulate benthic-pelagic coupling in Mobile Bay, and to calculate the percent contribution by the sediments to the total phytoplankton nutrient demand. Finally, these findings were compared with results from other systems in order to assess potential differences in factors regulating benthicpelagic coupling in different estuarine systems.

\section{METHODS}

Study site. Mobile Bay is $50 \mathrm{~km}$ long and 17 to $38 \mathrm{~km}$ wide (Schroeder 1977) with a surface area of $1060 \mathrm{~km}^{2}$ (NOAA/EPA 1989) and an average depth of $3 \mathrm{~m}$. The estuary has a small volume $\left(3.2 \times 10^{9} \mathrm{~m}^{3}\right.$; NOAA/EPA 1989) relative to freshwater input from the Alabama and Tombigbee Rivers, which combine to form the Mobile River system, the fourth largest in the USA (Morisawa 1968). River flow typically peaks in late winter to early spring ard is at a minimum in the summer to fall months. Average discharge from this system for the period 1929 to 1983 was $1848 \mathrm{~m}^{3} \mathrm{~s}^{-1}$ (Schroeder \& Wiseman 1986). This results in a very short average fresh water fill time of approximately $20 \mathrm{~d}$.

Physical forcings such as river discharge and high wind events strongly influence the hydrography of Mobile Bay. For example, salinity may range from 0 to 35 ppt in any one region of the bay over an annual cycle in response to river flow. Dissolved oxygen (DO) concentrations are also influenced by these physical dynamics. Strong stratification events (up to $12 \mathrm{ppt}$ differences in surface- and bottom-water salinities) may occur during periods of low river runoff when winds are low, during which time isolated bottom waters may become hypoxic or anoxic. This is apparently not a recent phenomenon, as newspaper accounts record the effects of low DO events as far back as 1867 (May 1973). Finally, physical forcings also affect sediment stability due to the shallow nature of the bay (Schroeder 1977. Stumpf 1991). Factors that cause destratification of the water column (high river flow and wind events) may also resuspend surficial sediments. Other studies have shown that this acts to initially increase the rate of release of nutrients from the sediments, but that a period of uptake by the sediments may follow once the resuspension event has ceased (Sondergaard et al. 1992, Vidal 1994). The frequency at which sediment resuspension occurs in Mobile Bay is not known at this time. However, seston data (Pennock et al. 1994a) suggests that it is more frequent in winter than in summer, and that it is not an uncommon event at any time of the year.

In order to measure sediment oxygen and nutrient fluxes in Mobile Bay, sediment samples were collected from a single station (Stn DR7) at a depth of $3 \mathrm{~m}$ in the northeastern part of the bay, where hypoxic/anoxic events are known to occur (Fig. 1). This station was occupied on average orce monthly during 1993 and 1994, and was occupied twice in August 1993. This region was chosen because it was also the site of 2 other studies, 1 concerned with oxygen variability ( $T$. Miller-Way et al unpubl data) and 1 studying the influence of oxygen variability on sediment-water nutrient fluxes (Fernandez 1995). Based on a 1 yr study of 9 stations distributed throughout Mobile Bay, sediment concentrations of particulate carbon (PC) particulate nitrogen (PN) and chlorophyll a (chl a) at Stn DR7 are fairly representative of the bay in general (Cowan unpubl. data).

Sediment oxygen consumption (SOC) and nutrient fluxes. For each experiment, 3 intact undisturbed sediment cores overlain with about $2000 \mathrm{ml}$ of water were collected in cylindrical Plexiglas chambers (34 cm high $\times 13.5 \mathrm{~cm}$ diameter) by SCUBA divers. 


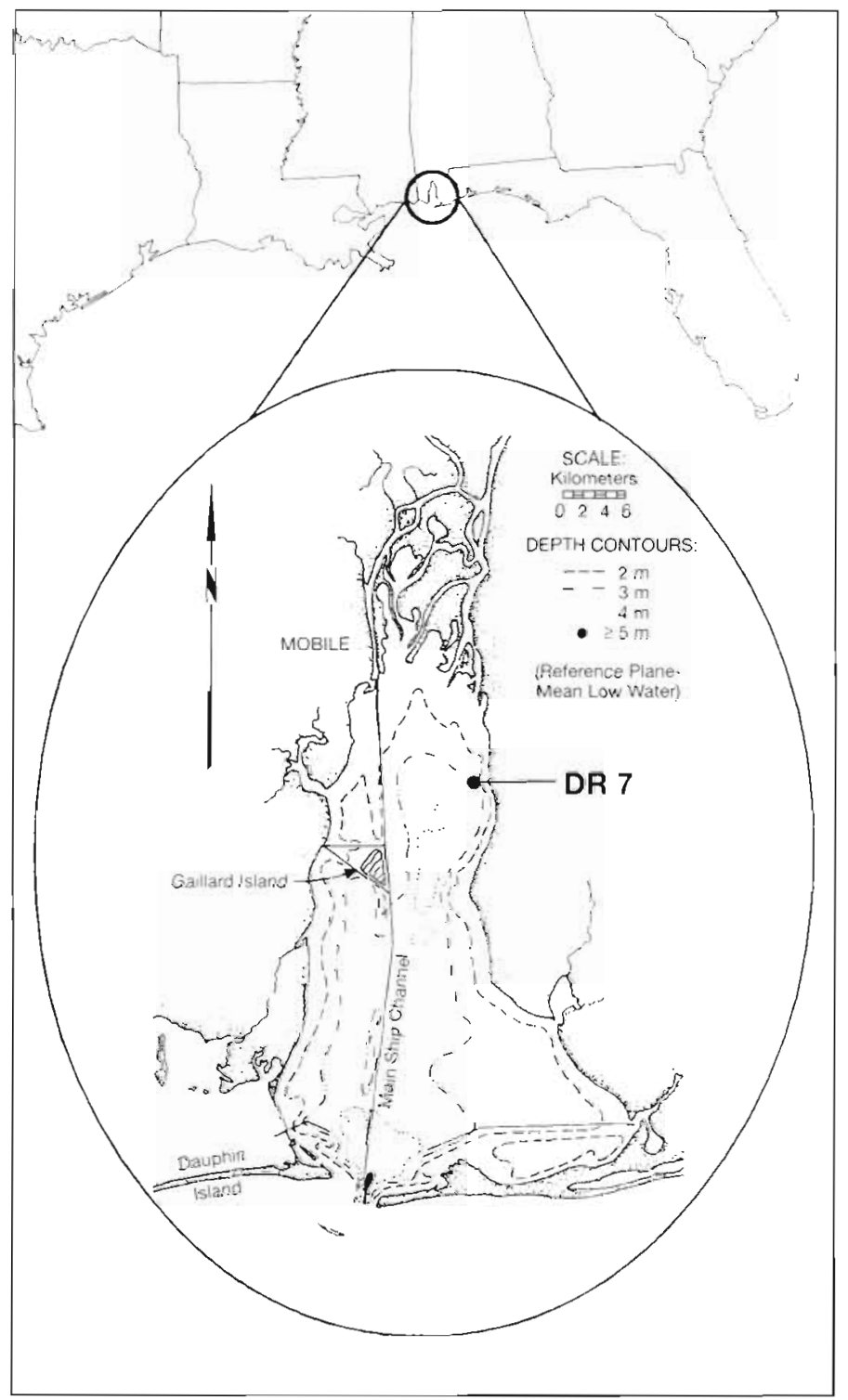

Fig. 1. Location of the sampling station in Mobile Bay, Alabama, USA (Stn DR7) in relation to depths of Mobile Bay and major freshwater sources

The cores were sealed air tight at both ends by Plexiglas plates (Fig. 2). The top plate had one portal for sampling and replacement water tubing, and a floating Teflon stir bar mounted to it for gentle mixing of the overlying water Approximately $90 \mathrm{l}$ of bottomwater were also collected in cubitainers using a Rule submersible pump. An additional flux chamber, filled with ambient bottom-water only, was used as a watercolumn control

Immediately prior to beginning flux measurements at the lab, bottom-water overlying the cores and in the water-column control was replaced with bottom-water from the cubitainers to insure that water quality condi- tions at the start of the experiment closely resembled in situ conditions. To do so, tubing drained water from the cubitainers into the existing water in the cores at a rate of approximately $0.95 \mathrm{lmin}^{-1}$ for about $20 \mathrm{~min}$, which was slow enough to prevent both aeration of the water and resuspension of the sediment. The cores were then placed in a darkened waterfilled incubator maintained at ambient temperature by a circulating constant temperature bath, and the sampling tubes were inserted. The total time that elapsed between collection of the cores and the start of the incubation was between 3 and $4 \mathrm{~h}$.

DO and dissolved inorganic nutrient samples were taken 5 times during a $6 \mathrm{~h}$ period. As a sample was extracted, an equal amount of ambient bottom-water drained in through the replacement tube from a darkened insulated cubitainer. Less than $5 \%$ of the overlying water was replaced during the course of the incubation period

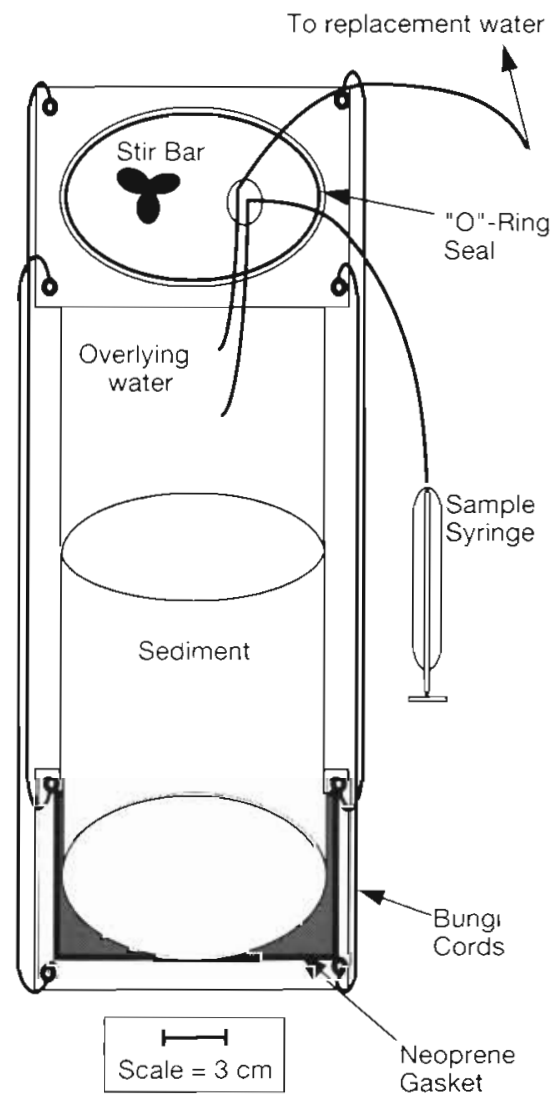

Fig. 2. Schematic diagram of the incubation chamber used in making measurements of net sediment-water nutrient and oxygen fluxes 
Nutrient samples were filtered through GF/C filters and frozen for later analysis of ammonium $\left(\mathrm{NH}_{4}^{+}\right)$ nitrate $\left(\mathrm{NO}_{3}^{-}\right)$nitrite $\left(\mathrm{NO}_{2}^{-}\right)$phosphate $\left(\mathrm{PO}_{4}^{-}\right)$and silicate (DSi) concentrations on an Alpkem Autoanalyzer, using methods as described in the Alpkem Manual (1988) and Parsons et al. (1984). DO samples were processed immediately, using methods described by Carpenter (1964) and modified for use with a Brinkman Metrohm titrator. Oxygen and nutrient fluxes were estimated by calculating the mean rate of change in concentration during the incubation period by regression analysis. Non-significant regressions ( $p>0.05)$ that were based on changes in concentration over time greater than the analytical variability were not used to calculate flux. Non-significant regressions based on changes over time that were less than the analytical variability were interpreted as net zero fluxes. For this study, analytical variability was defined as 2 standard deviations away from the mean of a standard solution within the range of the samples. The rate of change in the water-column control chamber was then subtracted from the rate of change in each sediment core, and this volumetric rate was converted to a flux using the measured volume:area ratio of each core.

Sediment characterization. Surface sediment samples were taken from each flux core at the end of each experiment for analysis of $\mathrm{PC}, \mathrm{PN}$, and chl a. Openended $20 \mathrm{ml}$ syringes were used to take subcores from which the top $0.5 \mathrm{~cm}$ (and in 1994, aiso the 0.5 to $1 \mathrm{~cm}$ interval) was removed and analyzed. Sediment chl a was analyzed fluorometrically according to methods described in Parsons et al. (1984). Sediment PC and PN were analyzed on a Carlo-Erba NA 1500 carbon, nitrogen, sulfur (CNS) analyzer according to methods described in Sharp (1974).
Water-column characterization. Water-column profiles of salinity, temperature, and DO were obtained with a Hydrolab H2O probe. Surface and bottom water samples were collected with the Rule pump, which was previously determined not to cause breakage of algal cells. Water samples were filtered and analyzed for chl a, $\mathrm{NH}_{4}{ }^{+}, \mathrm{NO}_{3}{ }^{-}, \mathrm{NO}_{2}^{-}, \mathrm{PO}_{4}^{-}, \mathrm{DSi}, \mathrm{PC}$ and $\mathrm{PN}$ as described above. Phytoplankton production rates were also measured from July 1993 to November 1994 using $24 \mathrm{~h}{ }^{14} \mathrm{C}$ incubations (Epply \& Sharp 1975) as modified for simulated in situ conditions by Pennock \& Sharp (1986). Water used for these measurements was retrieved using a Niskin bottle. Further details of the methods used may be found in Pennock et al. (1995).

\section{RESULTS AND DISCUSSION}

\section{Water-column and sediment characterization}

Temperature in the bottom $0.5 \mathrm{~m}$ of water at Stn DR7 followed a seasonal pattern $\left(7.8\right.$ to $30.3^{\circ} \mathrm{C}$ ) for the 1993 to 1994 period. Bottom-water salinity was quite variable, ranging from 0.0 to 20.1 ppt. River flow for this period closely followed the pattern for salinity, and the two were inversely correlated (Table 1). DO concentrations in bottom-waters varied from $<0.5$ to $9.9 \mathrm{mg} \mathrm{l}^{-1}$ (<13 to $107 \%$ saturation) with the lowest concentrations occurring in the summer months of both years (Fig. 3).

Ammonium concentrations in the bottom $0.5 \mathrm{~m}$ of water generally ranged from $<0.5$ to $7.9 \mu \mathrm{M}$, with a maximum of $24.3 \mu \mathrm{M}$ in September 1993 (Fig. 4). This parameter was negatively correlated with percent saturation of $\mathrm{DO}$ in the bottom-water, and was positively

Table 1. Results of product-moment correlation analyses for selected bottom-water variables. Nutrient concentrations (given in brackets) are in $\mu \mathrm{M}$; DO concentration is in $\mathrm{mg} \mathrm{l}^{-1} ; \%$ Sat. is DO percent saturation; salinity is in ppt; nver flow (R. flow) is in $\mathrm{m}^{3}$ $\$^{-1}$; stratification (Strat.) is bottom-surface water salinity; chl a is total chlorophyll a in $\mu g \mathrm{l}^{-1}$; PC and PN are in $\mu M_{i}$ C:N ratio is molar; $" p<0.10 ; " p<0.01$; all others $p<0.05$. Blank spaces indicate statistically insignificant relationships

\begin{tabular}{|c|c|c|c|c|c|c|c|c|c|c|}
\hline & DO & $\%$ Sat. & Salinity & {$\left[\mathrm{NH}_{4}{ }^{+}\right]$} & {$\left[\mathrm{NO}_{3}{ }^{-}\right]$} & {$\left[\mathrm{NO}_{2}{ }^{-}\right]$} & [DSi] & R. flow & Chl a & PC \\
\hline DO & 1.00 & & & & & & & & & \\
\hline$\%$ Sat. & $0.915^{\cdots}$ & 1.00 & & & & & & & & \\
\hline Salinity & $-0.357^{\circ}$ & -0.414 & 1.00 & & & & & & & \\
\hline$\left[\mathrm{NH}_{4}{ }^{+}\right]$ & & $-0.349^{\circ}$ & $0.407^{\circ}$ & 1.00 & & & & & & \\
\hline$\left[\mathrm{NO}_{3}^{-}\right]$ & 0.550 & $0.384^{\circ}$ & $-0.410^{\circ}$ & & 1.00 & & & & & \\
\hline$\left[\mathrm{NO}_{2}^{-}\right]$ & $0.556^{\circ}$ & $0.399^{\circ}$ & & & $0.909 \cdot \cdots$ & 1.00 & & & & \\
\hline$\left[\mathrm{PO}_{4}^{-1}\right]$ & -0.420 & -0.411 & $0.392^{\circ}$ & $0.928^{*}$ & & & & & & \\
\hline [DSi] & & & -0.564 & & $0.696 \cdots$ & $0.722 \cdots$ & 1.00 & & & \\
\hline R. flow & $0.564^{\cdots}$ & $0.370^{\circ}$ & -0.523 & & $0.734^{\cdots}$ & 0.566 & 0.600 & 1.00 & & \\
\hline Strat. & & -0.419 & 0.532 & $0.548 \cdots$ & $0.353^{\circ}$ & & & & & \\
\hline Chl a & & & & -0.462 & $-0.530 \cdot$ & -0.483 & & & 1.00 & \\
\hline $\mathrm{PC}$ & & & $-0.364^{\circ}$ & & & & & & $0.683^{\prime}$ & 1.00 \\
\hline PN & & & & $-0.364^{\circ}$ & $-0.383^{\circ}$ & $-0.388^{\circ}$ & & & $0.828^{\prime}$ & $0.891^{\prime \prime}$ \\
\hline C:N & $0.569^{\circ}$ & & & & $0.750^{\cdots}$ & $0.593^{*}$ & 0.540 & $0.693^{\cdots}$ & & $0.365^{\circ}$ \\
\hline
\end{tabular}



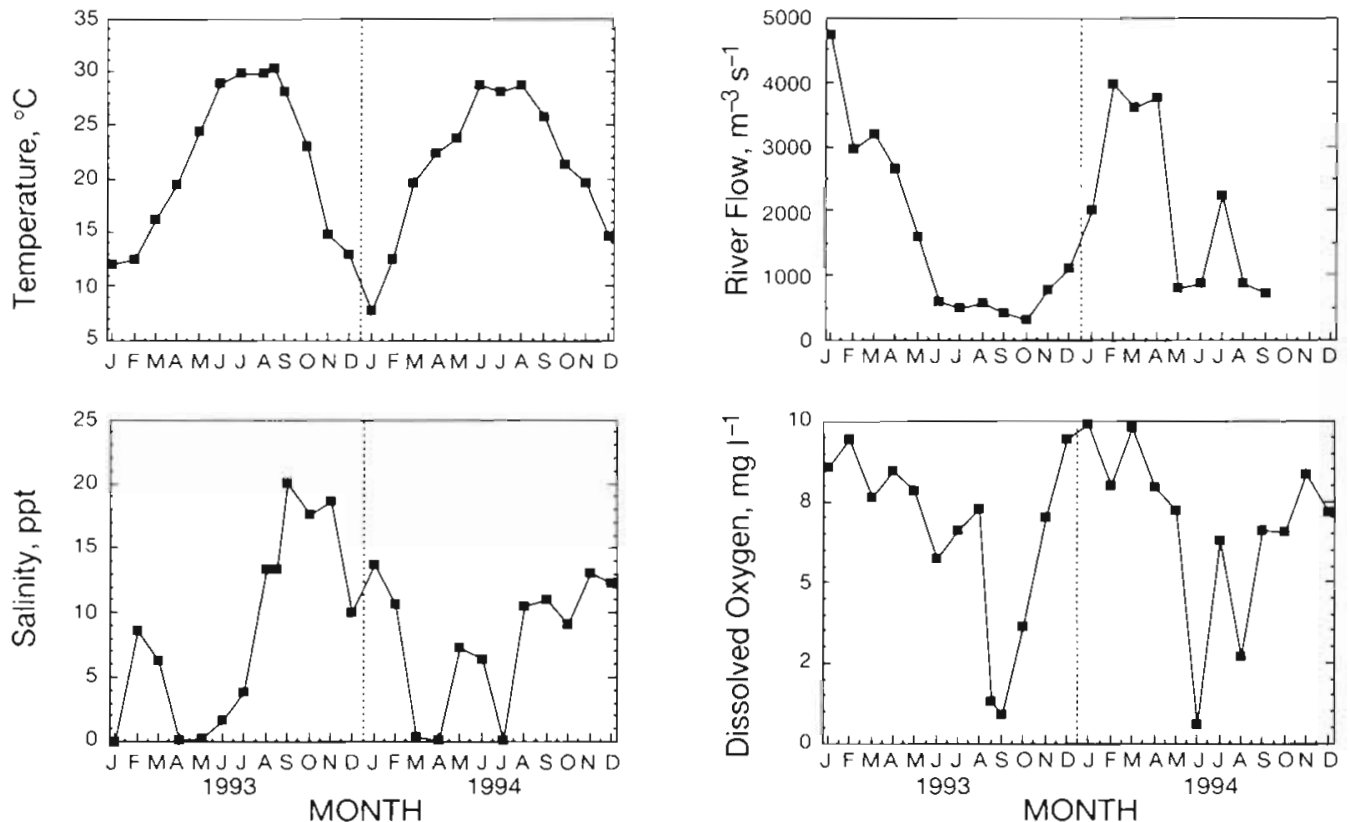

Fig. 3. Monthly bottom-water temperature, salinity, river flow, and dissolved oxygen conditions at Stn DR7 in Mobile Bay, for January 1993 to December 1994
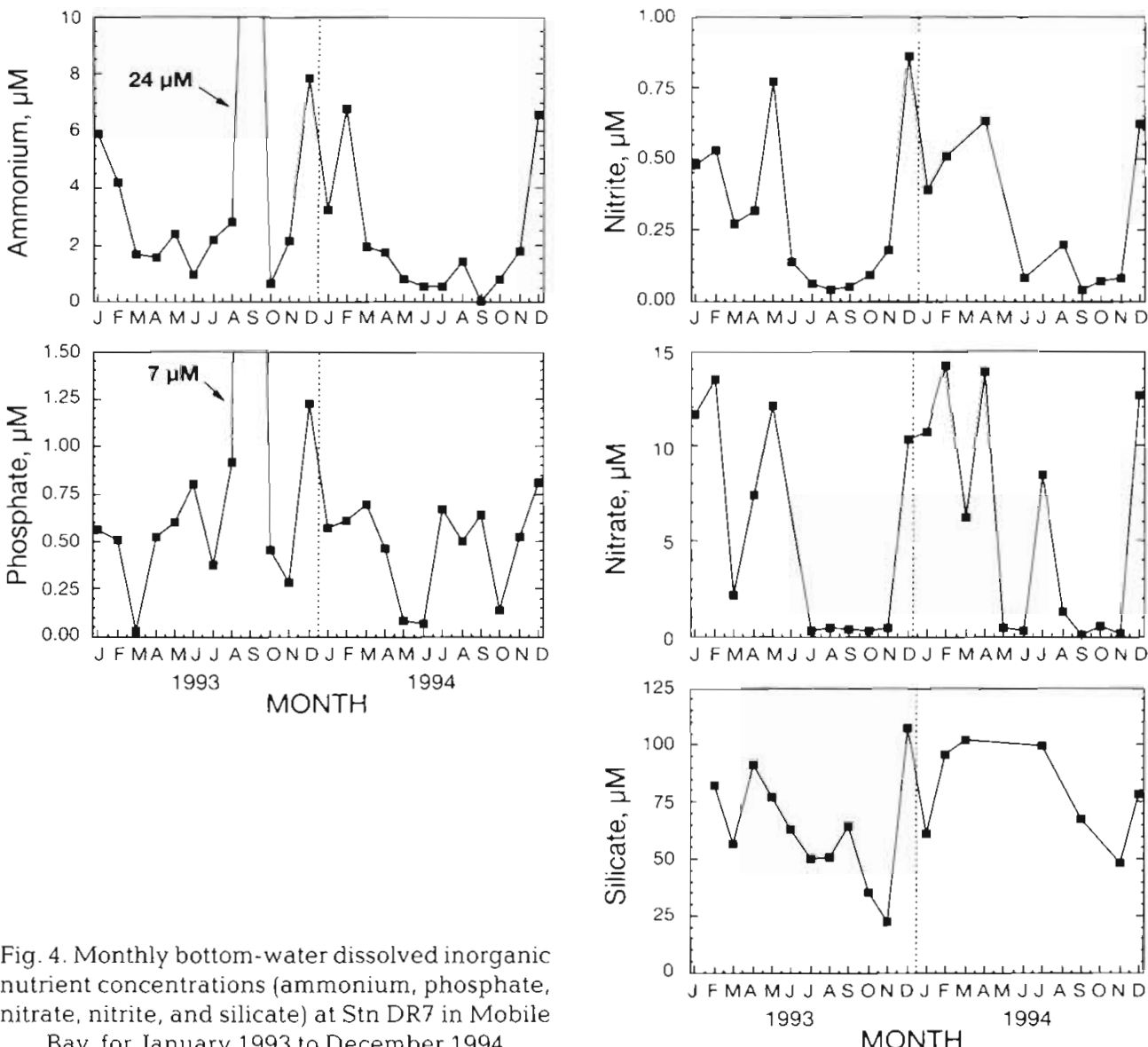

Fig. 4. Monthly bottom-water dissolved inorganic nutrient concentrations (ammonium, phosphate, nitrate, nitrite, and silicate) at Stn DR7 in Mobile Bay, for January 1993 to December 1994 
correlated with salinity and a stratification parameter (Table 1). This suggests that the major source of $\mathrm{NH}_{4}{ }^{+}$ for the bottom waters is from the sediments, as a stable water-column and low DO concentrations allow $\mathrm{NH}_{4}{ }^{+}$ to accumulate in the bottom-waters without being further speciated by nitrification. Concentrations of $\mathrm{PO}_{4}^{-}$ usually ranged from 0.07 to $1.23 \mu \mathrm{M}$ with a maximum of $7 \mu \mathrm{M}$ in September 1993 (Fig. 4). This nutrient was negatively correlated with bottom-water DO, which is consistent with the observation that $\mathrm{PO}_{4}^{-}$will sorb to $\mathrm{FeOOH}^{-}$and clay particles under oxic conditions and desorb under hypoxic/anoxic conditions (Patrick \& Khalid 1974).

Bottom-water concentrations of $\mathrm{NO}_{3}^{-} \quad(<0.10$ to $14.1 \mu \mathrm{M})$ and $\mathrm{NO}_{2}^{-}(<0.05$ to $0.86 \mu \mathrm{M})$ were positively correlated with bottom-water DO, percent saturation of DO, and river flow (Fig. 4, Table 1). The former 2 correlations reflect the sensitivity of these nitrogen species to fluctuating $D O$ concentrations relative to nitrification/denitrification processes, while the latter indicates an allochthonous source for these nutrients. Finally, concentration of DSi (35 to $107 \mu \mathrm{M}$ ) was correlated positively with $\mathrm{NO}_{3}^{-}+\mathrm{NO}_{2}^{-}$concentration, $\mathrm{NO}_{2}^{-}$ concentration, and river flow, and was negatively correlated with salinity. These relationships suggest that there is largely an external source for this nutrient as well.

Total chl a concentrations (chl a plus phaeopigments) in the bottom-water ranged from 5 to $45 \mathrm{mg} \mathrm{I}^{-1}$ over the 2 annual cycles, but followed no distinctive seasonal pattern (Fig. 5). The pattern for chl a (the 'active' portion of the total pool) paralleled that of total chl $a$; however, the concentrations ranged only from 0.4 to $22 \mu \mathrm{g} \mathrm{l}^{-1}$. Total chl a was inversely correlated with dissolved inorganic nitrogen (DIN) concentrations and positively correlated with bottom-water PC and PN concentrations (Table 1). As with chl a, no seasonal pattern could be discerned in the bottom-water concentrations of PC (42.5 to $217 \mu \mathrm{M}$ ) and PN (5 to $24 \mu \mathrm{M}$ ) but both were positively correlated with total chl $a$ and with each other (Table 1), suggesting that phytoplankton are a major component of PC and PN in the watercolumn.

Bottom-water $\mathrm{C}: \mathrm{N}$ ratios were calculated to characterize the existing particulate material relative to organic material of phytoplanktonic origin ( $\mathrm{C}: \mathrm{N}=6.6$; Redfield 1934). The greatest departures from this ratio came when river flow was highest, suggesting that more refractory material is introduced to the system from the rivers during peak flow. However, more labile phytoplanktonic detritus appears to make up the majority of the particulate material in the bottomwaters during periods of low flow.

In the top $0.5 \mathrm{~cm}$ of sediment, the concentration of total sediment chl a ranged from 37 to $56 \mathrm{mg} \mathrm{m}^{-2}$, and
$\mathrm{PC}$ and $\mathrm{PN}$ ranged from 1.4 to $3.0 \%$ and from 0.14 to $0.28 \%$ dry weight, respectively (Fig. 6). Patterns of PC and PN were very similar and were strongly correlated. Sediment PN was also positively correlated with sediment chl a. Sediment C:N ratios ranged from 8.9 to
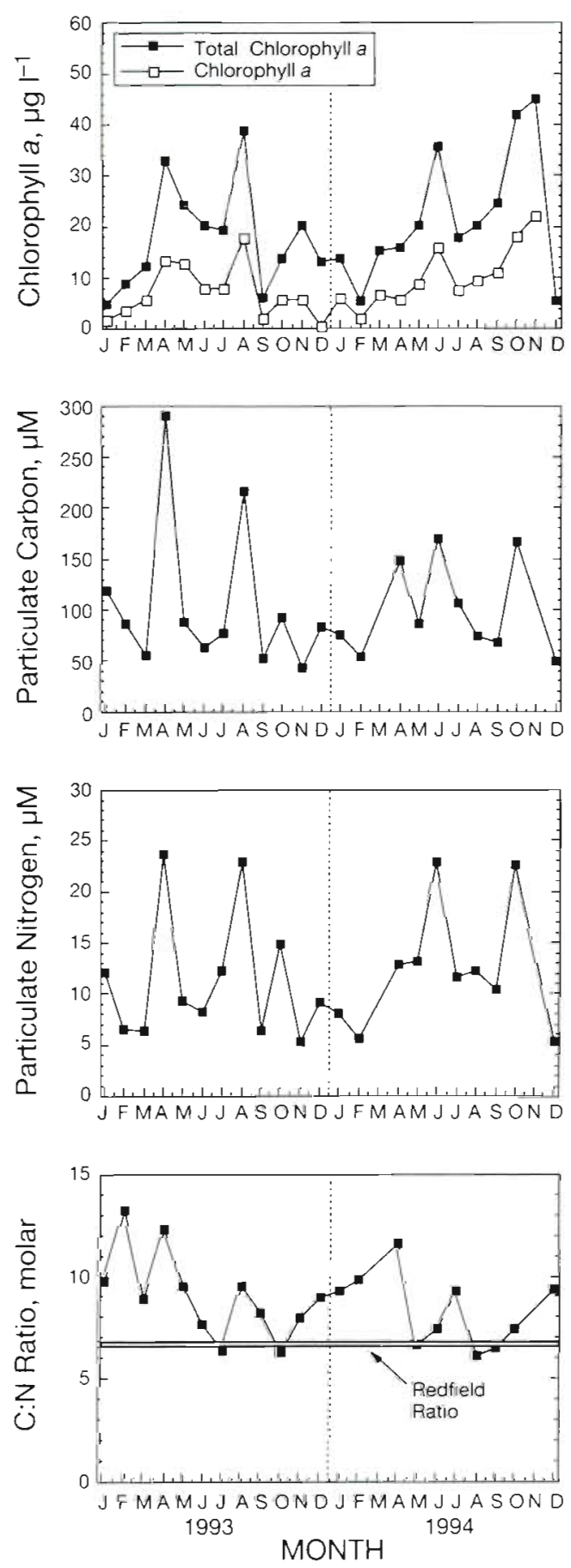

Fig. 5. Monthly bottom-water total chl a (active plus phaeopigments) and chl a: particulate carbon, and particulate nitrogen concentrations; and particulate C: $N$ ratios at Stn DR7 in Mobile Bay, for January 1993 to December 1994 

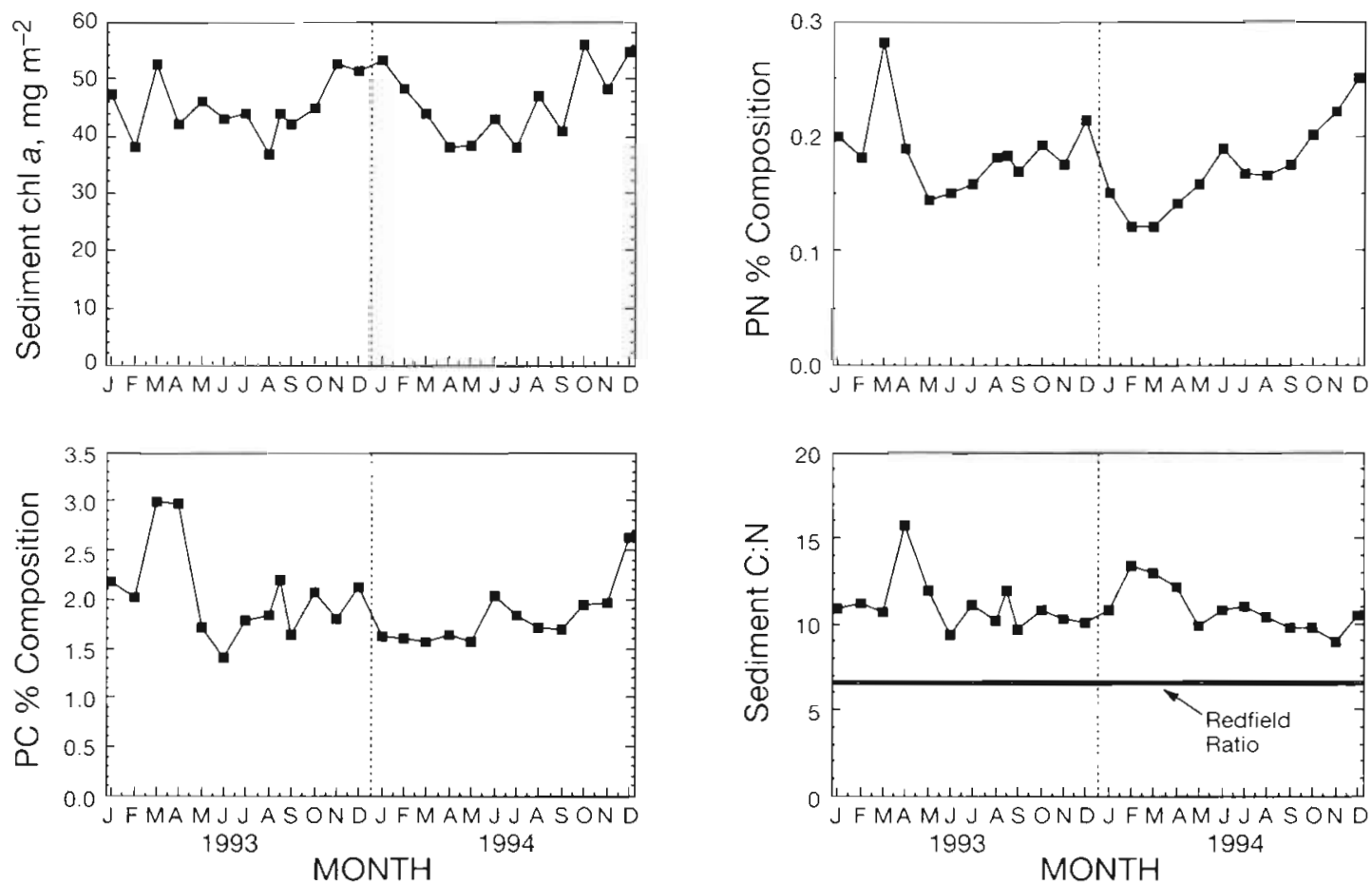

Fig. 6. Monthly sediment total chl a, PC, and PN compositions; and sediment particulate C: $\mathrm{N}$ ratios at the 0 to $0.5 \mathrm{~cm}$ depth interval for Stn DR7 in Mobile Bay, for January 1993 to December 1994

Table 2. Rates of sediment-water exchanges of oxygen and nutrients for selected estuaries. Sediment oxygen consumption (SOC) rates are in $\mathrm{gO}_{2} \mathrm{~m}^{-2} \mathrm{~d}^{-1}$; all nutrient fluxes are in $\mu \mathrm{mol} \mathrm{m}^{-2} \mathrm{~h}^{-1}$

\begin{tabular}{|c|c|c|c|c|c|c|c|c|}
\hline Site & \multicolumn{2}{|c|}{$\begin{array}{l}\text { Months } \\
\text { of study }\end{array}$} & $\begin{array}{l}\text { Depth } \\
\text { (m) }\end{array}$ & $\mathrm{SOC}$ & $\mathrm{NH}_{4}^{+}$ & $\mathrm{NO}_{3}^{-}$ & $\mathrm{PO}_{4}^{-}$ & DSi \\
\hline Mobile Bay, AL' & \multicolumn{2}{|c|}{ Jan-Dec } & 3 & $0.1-1.25$ & $-22-181$ & $-14-67$ & $-2-20$ & $-15-342$ \\
\hline Texas Coast ${ }^{b}$ & \multicolumn{2}{|c|}{ July, Oct } & 14 & $1.05-5.12$ & $43-315$ & & & \\
\hline Fourleague Bay, LA' & \multicolumn{2}{|c|}{ Aug-May } & 1.5 & $0-3.43$ & $-50-450$ & $-680-620$ & $-50-18$ & \\
\hline South River, NC ${ }^{d}$ & \multicolumn{2}{|c|}{ Jan-Dec } & 2 & $0.71-2.72$ & $0.0-267$ & $0.0-5.8$ & $-8.3-23$ & \\
\hline Neuse River, $\mathrm{NC}^{\mathrm{d}}$ & \multicolumn{2}{|c|}{ Jan-Dec } & 3 & $0.70-1.87$ & $71-454$ & $0.0-6.4$ & $-2.3-46$ & \\
\hline Cape Lookout Bight, $\mathrm{NC}^{\mathrm{C}}$ & \multicolumn{2}{|c|}{ Feb-Nov } & 5.5 & & $28-1023$ & & $-17-97$ & \\
\hline \multicolumn{9}{|l|}{ Chesapeake Bay ${ }^{i}$} \\
\hline North Bay, MD & \multicolumn{2}{|c|}{ Jan-Dec } & 9 & $0.1-0.65$ & $-34-101$ & $-117-9$ & $-16-3$ & $-34-202$ \\
\hline Mid Bay, MD & \multicolumn{2}{|c|}{ Jan-Dec } & 16 & $0.01-0.86$ & $9-507$ & $-100-12$ & $0-148$ & $57-358$ \\
\hline Lower Bay, VA & \multicolumn{2}{|c|}{ Jan-Dec } & 11 & $0.3-0.75$ & $15-181$ & $-8-19$ & $-1.5-13$ & $63-255$ \\
\hline Patuxent River, MD" & \multicolumn{2}{|c|}{ May-Oct } & 3 & $0.75-2.25$ & $10-200$ & $12.5-37.5$ & $0-15$ & $110-575$ \\
\hline Long Island Sound, NY ${ }^{h}$ & \multicolumn{2}{|c|}{ Mar-Oct } & 14 & & $12-133$ & & & $46-442$ \\
\hline Narraganset Bay, RI' & \multicolumn{2}{|c|}{ Jan, July } & -8 & & $75-500$ & & $38-233$ & $42-346$ \\
\hline San Francisco Bay, CA, Stn 27.51 & \multicolumn{2}{|c|}{ Feb-Nov } & 14 & $0.35-0.70$ & $17-208$ & $0-33$ & $-4.2-54$ & $88-292$ \\
\hline Aarhus Bight, Denmark ${ }^{k}$ & \multicolumn{2}{|c|}{ Jan-Dec } & $\sim 15$ & & $8-62.5$ & $-33-14.6$ & & \\
\hline Sea of Japan' & \multicolumn{2}{|c|}{ Apr-Nov } & 7 & & $4-21$ & & $1.8-26$ & $88-499$ \\
\hline Bay of Cadız, Spain ${ }^{m}$ & \multicolumn{2}{|c|}{ Mar-Jan } & 8.5 & $2.2-7.5$ & $258-1525$ & & $21-379$ & $258-1479$ \\
\hline \multicolumn{2}{|l|}{ 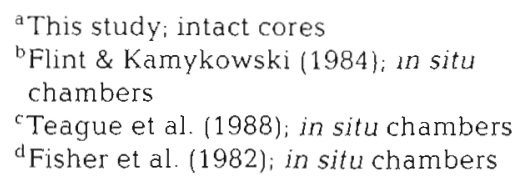 } & \multicolumn{4}{|c|}{$\begin{array}{l}\text { 'Klump \& Martens (1981); in situ chambers } \\
\text { 'Cowan \& Boynton (1995); intact cores } \\
\text { 'Boynton et al. (1991); intact cores } \\
\text { 'Aller \& Benninger (1981); intact cores } \\
\text { ' Elderfield et al. (1981); in situ chambers }\end{array}$} & \multicolumn{3}{|c|}{$\begin{array}{l}\text { Hammond et al. (1985): in situ } \\
\text { chambers } \\
\text { "Jensen et al. (1990); intact cores } \\
\text { ' Propp et al. (1980); in situ chambers } \\
\text { "Forja et al. (1994); in situ chambers }\end{array}$} \\
\hline
\end{tabular}


15.7 over the 2 yr and were positively correlated with river flow. These sediment data agree well with trends in the water-column chl $a$ and $\mathrm{C}: \mathrm{N}$ data, and indicate that riverine material possesses a high $\mathrm{C}: \mathrm{N}$ ratio compared to that of autochthonous origin.

\section{Patterns of oxygen and nutrient flux}

The mean rate of sediment oxygen consumption (SOC) in 1993 and 1994 was 0.58 and $0.54 \mathrm{gO}_{2} \mathrm{~m}^{-2} \mathrm{~d}^{-1}$, respectively. Monthly rates of SOC (average of 3 replicate cores) ranged from 0.10 to $1.25 \mathrm{gO}_{2} \mathrm{~m}^{-2} \mathrm{~d}^{-1}$ during the 2 yr (Fig. 7). The lowest rate of SOC occurred in September 1993, during an extended hypoxic period
(T. Miller-Way et al. unpubl. data). Otherwise, the lowest rates of $\mathrm{SOC}$ measured (approximately $0.25 \mathrm{gO}_{2}$ $\mathrm{m}^{-2} \mathrm{~d}^{-1}$ ) occurred in colder months, while highest rates were measured in warmer months. These rates are moderate relative to rates measured in other estuaries (Table 2).

The mean of fluxes of $\mathrm{NH}_{4}^{+}$in 1993 and in 1994 were 70.0 and $38.5 \mu \mathrm{mol} \mathrm{m} \mathrm{m}^{-2} \mathrm{~h}^{-1}$, respectively. During the $2 \mathrm{yr}$, monthly fluxes ranged from a small uptake of $22.3 \mu \mathrm{mol} \mathrm{m} \mathrm{m}^{-2} \mathrm{~h}^{-1}$ (Fig. 7, shown as a negative rate) to a maximum release of $180.5 \mu \mathrm{mol} \mathrm{m} \mathrm{m}^{-2} \mathrm{~h}^{-1}$. Uptake of $\mathrm{NH}_{4}{ }^{+}$by the sediments was rare, occurring only once during the study, and maximum rates of release always occurred in warmer months. These rates of release are moderate compared to other estuaries (Table 2).
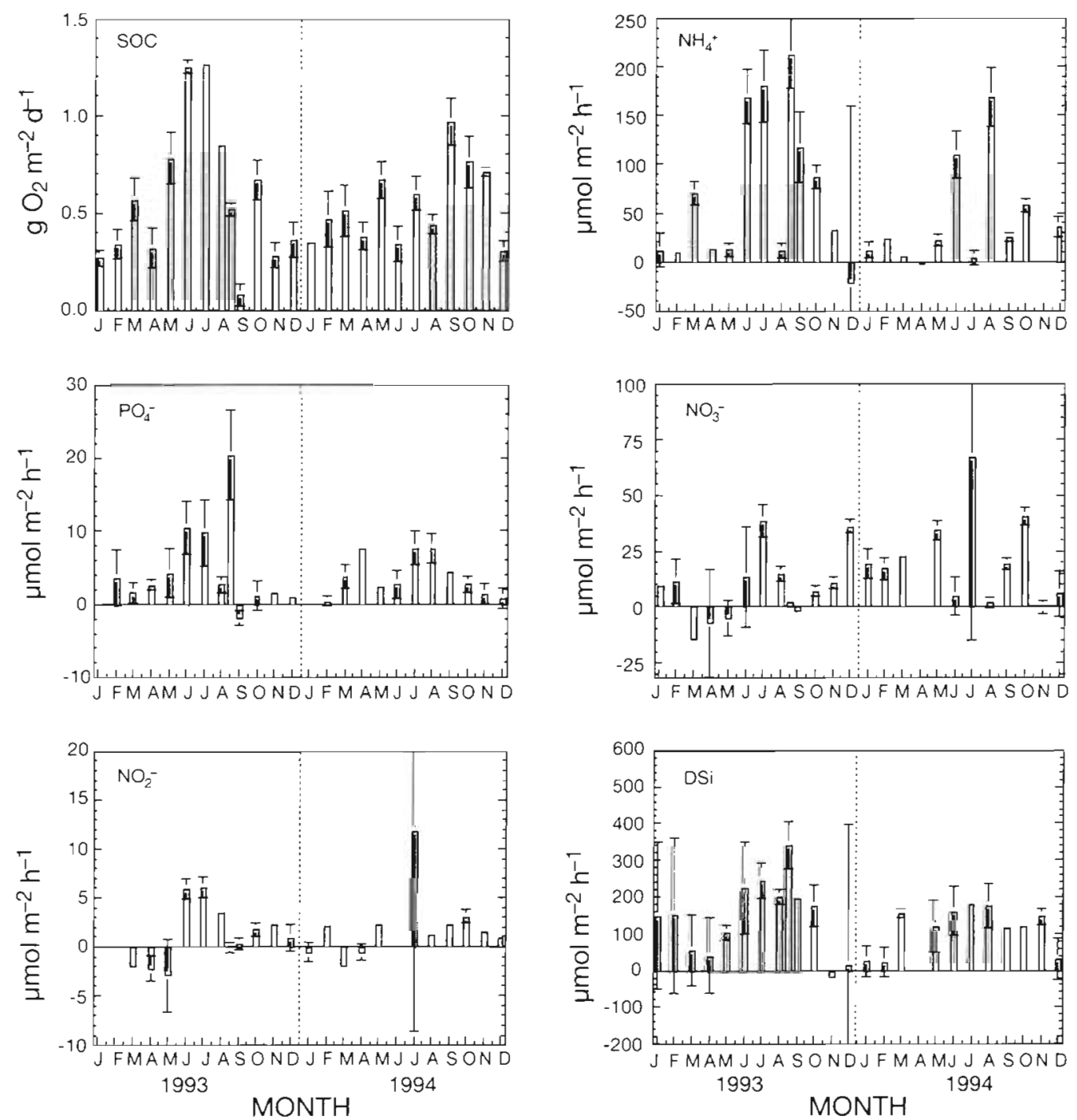

Fig. 7. Monthly averaged values (mean \pm standard deviation) of sediment oxygen consumption (SOC), ammonium flux ( $\mathrm{NH}_{4}{ }^{+}$), phosphate flux $\left(\mathrm{PO}_{4}^{-}\right)$, nitrate flux $\left(\mathrm{NO}_{3}^{-}{ }^{-}\right.$, nitrite flux $\left(\mathrm{NO}_{2}^{-}\right)$, and silicate flux (DSi) at Stn DR7 in Mobile Bay from January 1993 to December 1994. All SOC measurements represent oxygen uptake by the sediments; positive and negative nutrient fluxes represent fluxes out of and into the sediments, respectively 
Mean fluxes of $\mathrm{PO}_{4}^{-}$in 1993 and 1994 were 4.4 and $3.5 \mu \mathrm{mol} \mathrm{m} \mathrm{m}^{-2} \mathrm{~h}^{-1}$, respectively. Monthly fluxes ranged from near zero $(-1.9)$ to $20.4 \mu \mathrm{mol} \mathrm{m} \mathrm{m}^{-2} \mathrm{~h}^{-1}$ (Fig. 7). Uptake of $\mathrm{PO}_{4}^{-}$occurred only once (September 1993), when the concentration of $\mathrm{PO}_{4}^{-}$in the bottom-water was about 7 times higher than that measured at any other time in the 2 yr sampled. The maximum release of $20.4 \mu \mathrm{mol} \mathrm{m} \mathrm{m}^{-2} \mathrm{~h}^{-1}$ occurred in late August 1993 when the bottom-water had been hypoxic for nearly 1 wk prior to sampling (T. Miller-Way et al. unpubl. data). While this rate was unusually high for the 2 yr sampled, it does show the potential these sediments have to release $\mathrm{PO}_{4}^{-}$during extended hypoxic periods. These fluxes are low to moderate compared to other estuaries (Table 2).

Both $\mathrm{NO}_{3}^{-}$and $\mathrm{NO}_{2}^{-}$fluxes were variable over the sample period. However, the direction of both nutrient fluxes tended to be the same at any given time. Mean fluxes of $\mathrm{NO}_{3}{ }^{-}$in 1993 and 1994 were 8.9 and $19.5 \mu \mathrm{mol} \mathrm{m} \mathrm{m}^{-2} \mathrm{~h}^{-1}$, respectively. Mean fluxes of $\mathrm{NO}_{2}{ }^{-}$for these $2 \mathrm{yr}$ were 1.06 and $1.86 \mu \mathrm{mol} \mathrm{m} \mathrm{m}^{-2} \mathrm{~h}^{-1}$, respectively. Monthly fluxes of $\mathrm{NO}_{3}^{-}$ranged from -14.1 to $67.3 \mu \mathrm{mol} \mathrm{m} \mathrm{m}^{-2} \mathrm{~h}^{-1}$; those of $\mathrm{NO}_{2}^{-}$ranged from -2.9 to $20.4 \mu \mathrm{mol} \mathrm{m} \mathrm{m}^{-2}$ $\mathrm{h}^{-1}$ (Fig. 7). Rates of uptake of $\mathrm{NO}_{3}^{-}$are low compared to other estuaries, but rates of release are moderate to high (Table 2).

On all but one occasion, fluxes of DSi were directed out of the sediments. Mean fluxes in 1993 and 1994 were 144.8 and $104.4 \mu \mathrm{mol} \mathrm{m} \mathrm{m}^{-2} \mathrm{~h}^{-1}$, respectively. Monthly averaged fluxes ranged from -15.9 to $342.0 \mu \mathrm{mol} \mathrm{m}^{-2} \mathrm{~h}^{-1}$, and the highest rates were measured in the warmest months of both years (Fig. 7). These rates of uptake are high and release rates are moderate to high compared to those measured in other estuaries (Table 2).

\section{Factors regulating temporal variations in fluxes}

Many factors have been shown to influence rates of nutrient regeneration and microbial transformation of those nutrients. However, few attempts have been made to quantitatively rank these variables according to their relative influence on fluxes, and to determine how much variability may be described using parameters measured in the field. In an attempt to do so, data for selected bottom-water, sediment and flux parameters in Mobile Bay were examined using a stepwise regression model (Statistica/Mac, Statsoft 1991). The parameters included were chosen based on significant findings of product-moment correlation analyses (Statistica/Mac, Statsoft 1991; Table 3) and on biologically based a priori assumptions. Many combinations were tested, and those that best described the variability in the data set are shown in Table 4.

Overall, bottom-water temperature and/or DO concentration best explained variability measured in fluxes due to their influence on a variety of microbial and physico-chemical processes. For example, temper-
Table 3. Results of product-moment correlation analyses of fluxes and selected bottom-water and sediment variables. All nutrient fluxes are in $\mu \mathrm{mol} \mathrm{m} \mathrm{m}^{-2} \mathrm{~h}^{-1}$ SOC is in $\mathrm{gO}_{2} \mathrm{~m}^{2} \mathrm{~d}^{-1} ; \mathrm{p}<0.10 ; \cdots \mathrm{p}<0.01$; all others $\mathrm{p}<0.05$ Blank spaces indicate statistically insignificant relationships

\begin{tabular}{|c|c|c|c|c|c|c|}
\hline & \multicolumn{6}{|c|}{ Fluxes } \\
\hline & $\mathrm{SOC}$ & $\mathrm{NH}_{4}^{+}$ & $\mathrm{NO}_{3}^{-}$ & $\mathrm{NO}_{2}^{-}$ & $\mathrm{PO}_{4}^{-}$ & $\mathrm{DSi}$ \\
\hline $\mathrm{SOC}$ & 1.00 & & & & & \\
\hline \multicolumn{7}{|l|}{ Fluxes: } \\
\hline $\mathrm{NH}_{4}^{+}$ & & 1.00 & & & & \\
\hline $\mathrm{NO}_{3}^{-}$ & $0.337^{\circ}$ & & 1.00 & & & \\
\hline $\mathrm{NO}_{2}^{-}$ & 0.480 & & $0.812^{\cdots}$ & 1.00 & & \\
\hline $\mathrm{PO}_{4}^{-}$ & & 0.489 & & & 1.00 & \\
\hline $\mathrm{DSi}$ & $0.375^{\circ}$ & $0.592 \cdots$ & & $0.359^{\circ}$ & & 1.00 \\
\hline \multicolumn{7}{|l|}{ Bottom-water: } \\
\hline Chl a $\left(\mu g l^{-1}\right)$ & $0.384^{\circ}$ & & & & & \\
\hline Temp. $\left({ }^{\circ} \mathrm{C}\right)$ & 0.492 & $0.607 \cdots$ & & $0.386^{\circ}$ & $0.359^{\circ}$ & $0.694^{\prime} \cdot$ \\
\hline Salinity (ppt) & & & & & $-0.389^{\circ}$ & \\
\hline $\mathrm{DO}\left(\mathrm{mg} \mathrm{l}^{-1}\right)$ & & $-0.753 \cdots$ & & & & $-0.533^{\cdots} \cdot$ \\
\hline$\left[\mathrm{NO}_{3}\right](\mu \mathrm{M})$ & $-0.401^{*}$ & $-0.537^{\cdots}$ & & & & -0.381 \\
\hline$\left[\mathrm{NO}_{2}^{-}\right](\mu \mathrm{M})$ & $-0.379^{\circ}$ & -0.553 & & -0.514 & & -0.505 \\
\hline \multicolumn{7}{|l|}{ Sediments: } \\
\hline $\mathrm{PC}(\%)$ & & & $-0.375^{\circ}$ & & & $-0.349^{\circ}$ \\
\hline $\mathrm{C}: \mathrm{N}$ & & & & $-0.368^{\circ}$ & & \\
\hline Chl a $\left(\mathrm{mg} \mathrm{m}^{-2}\right)$ & & & & & $-0.468^{\circ}$ & \\
\hline R. Flow $\left(\mathrm{m}^{3} \mathrm{~s}^{-1}\right)$ & $-0.390^{\circ}$ & -0.503 & & & & -0.457 \\
\hline
\end{tabular}

Table 4. Results of most significant step-wise regression analyses. Variables used in each regression analysis were independent of each other

\begin{tabular}{|c|c|c|c|c|}
\hline Flux & Variable & $r^{2}$ & Cumulative $r^{2}$ & p-level \\
\hline $\mathrm{SOC}$ & $\begin{array}{l}\text { Bottom-water temperature } \\
\text { Bottom-water DO }\end{array}$ & $\begin{array}{l}0.242 \\
0.281\end{array}$ & 0.527 & $\begin{array}{l}0.06 \\
0.02\end{array}$ \\
\hline $\mathrm{NH}_{4}^{+}$ & $\begin{array}{l}\text { Bottom-water DO } \\
\text { SOC }\end{array}$ & $\begin{array}{l}0.566 \\
0.116\end{array}$ & 0.682 & $\begin{array}{l}0.001 \\
0.04\end{array}$ \\
\hline $\mathrm{NO}_{3}^{-}$ & $\begin{array}{l}\mathrm{NO}_{2}^{-} \text {flux } \\
\text { Bottom-water DO }\end{array}$ & $\begin{array}{l}0.659 \\
0.068\end{array}$ & 0.727 & $\begin{array}{l}0.000 \\
0.095\end{array}$ \\
\hline $\mathrm{NO}_{2}^{-}$ & $\begin{array}{l}\mathrm{NO}_{3}^{-} \text {flux } \\
\text { Bottom-water temperature }\end{array}$ & $\begin{array}{l}0.659 \\
0.082\end{array}$ & 0.741 & $\begin{array}{l}0.000 \\
0.02\end{array}$ \\
\hline $\mathrm{PO}_{4}^{-}$ & $\begin{array}{l}\mathrm{NH}_{4}^{*} \text { flux } \\
\text { Bottom-water salinity }\end{array}$ & $\begin{array}{l}0.385 \\
0.124\end{array}$ & 0.509 & $\begin{array}{l}0.000 \\
0.03\end{array}$ \\
\hline DSi & Bottom-water temperature & 0.482 & 0.482 & 0.000 \\
\hline
\end{tabular}


ature explained $48 \%$ of the month to month variability in DSi fluxes. Because Si dissolution is physically rather than biologically driven, dissolution rates increase exponentially with temperature (Kamatani 1982, Conley \& Malone 1992). Salinity has also been found by others to affect Si dissolution rates, and thus fluxes (Paasche 1980); however, data from this study showed no such correlation. Uptake by benthic microalgae may also influence rates of DSi release (Sundbäck et al, 1991, Rizzo et al. 1992). However, a comparison of all nutrient and oxygen fluxes measured under the highest light conditions observed in this study $\left(48 \mu \mathrm{E} \mathrm{m}^{-2} \mathrm{~s}^{-1}\right)$ showed no difference from those measured under dark conditions, suggesting that benthic microalgae exert little influence on rates of nutrient fluxes at this site in Mobile Bay.

Bottom-water temperature and DO described $53 \%$ of the variability in measured rates of SOC. These results reflect the positive influence of temperature on sediment metabolism (Hargrave 1973, Nixon et al. 1976, Klump \& Martens 1981), which is moderated when DO concentrations are very low (e.g. late August and September 1993, June and August 1994).

Bottom-water DO, and to a lesser extent temperature, strongly influenced nitrogen fluxes due to complex interactions between these factors and processes of ammonification, nitrification, and denitrification. A combination of bottom-water DO and SOC explained $68 \%$ of the variability in $\mathrm{NH}_{4}{ }^{+}$fluxes; flux of $\mathrm{NO}_{2}{ }^{-}$and bottom-water DO described approximately $73 \%$ of the measured variability in $\mathrm{NO}_{3}^{-}$fluxes; and flux of $\mathrm{NO}_{3}{ }^{-}$ and temperature described $74 \%$ of the variability in $\mathrm{NO}_{2}^{-}$fluxes. Temperature was also correlated with $\mathrm{NH}_{4}{ }^{+}$flux, although it was not a part of the step-wise regression model because it is cross-correlated with SOC (Table 3).

These results not only show the sensitivity of microbial processes to temperature, but also reflect the probable suppression of nitrification under low DO conditions (Kemp et al. 1990), and underscore the role that $\mathrm{NO}_{2}^{-}$plays as an intermediate species in both processes of nitrification and denitrification. In fact, in each year the highest $\mathrm{NH}_{4}{ }^{+}$release rates and nearzero $\mathrm{NO}_{3}^{-}$and $\mathrm{NO}_{2}^{-}$fluxes from the sediments occurred in the warmest months when the bottomwaters were hypoxic (late August and September 1993, June and August 1994). In contrast, fluxes of $\mathrm{NO}_{3}{ }^{-}$and $\mathrm{NO}_{2}{ }^{-}$were highest in the warmest oxidized months, while fluxes of $\mathrm{NH}_{4}{ }^{+}$tended to be lowest under these conditions. These patterns suggest that nitrification is suppressed under hypoxic conditions, and that nitrification rates are high enough under oxic conditions to oxidize almost all of the regenerated nitrogen before it is released from the sediments. It may be noted, though, that high $\mathrm{NH}_{4}{ }^{+}$releases did occur in June and July 1993 under well oxidized conditions. Concurrently measured high releases of $\mathrm{NO}_{3}{ }^{-}$ suggest that rates of decomposition at these times were higher than rates of nitrification, resulting in high releases of both reduced and oxidized forms of nitrogen.

Microbial and macrofaunal biomass may also influence nitrogen fluxes, as they affect rates of nitrification and denitrification. Activity by large macrofauna has also been shown to increase release of nutrients by increasing irrigation of sediments when bioturbation is great (e.g. Henriksen et al. 1983). However, macroinfaunal biomass in Mobile Bay, consisting of small surface-dwelling species associated with pioneer communities, is quite low and sometimes absent and thus was probably not a dominant factor influencing fluxes (Rhoades et al. 1978, Dardeau et al. 1990). Variability in microbial biomass, however, could have had a significant influence on nitrogen fluxes (van Duyl et al. 1993), particularly as it influences rates of nitrification and denitrification (Nedwell et al. 1983, Henriksen \& Kemp 1988, Kemp et al. 1990). While denitrification was not measured in this study, rates estimated from these data (see below) suggest that denitrification may be substantial. In addition, nitrification is evidently an important feature during warm months when bottom waters are oxidized. Thus, $\mathrm{NH}_{4}{ }^{+}$flux would likely be inversely correlated with nitrification and, because denitrification is strongly coupled to nitrification in most marine sediments (Seitzinger 1988), $\mathrm{NO}_{3}^{-}$flux would likely be inversely correlated with denitrification in Mobile Bay.

About $51 \%$ of the variability in $\mathrm{PO}_{4}^{-}$flux was explained by $\mathrm{NH}_{4}{ }^{+}$flux and salinity. The inverse relationship between $\mathrm{PO}_{4}^{-}$flux and salinity (Table 3 ) is counterintuitive, because $\mathrm{PO}_{4}^{-}$is believed to sorb more strongly with particles in fresh and brackish waters than in sea water due to the decreased competition for adsorption sites by other ions (particularly sulfate) in the water (Caraco et al. 1989). However, a positive relationship between $\mathrm{NH}_{4}{ }^{+}$and $\mathrm{PO}_{4}{ }^{-}$fluxes was also found by Fisher et al. (1982), who attributed it to the relative mobility of both nutrients in the sediments. Yet, this relationship only explained about $39 \%$ of the variability in $\mathrm{PO}_{4}{ }^{-}$fluxes in Mobile Bay. If $\mathrm{NH}_{4}{ }^{+}$flux is removed from the regression model, temperature appears as the only significant factor affecting variability in $\mathrm{PO}_{4}^{-}$fluxes $(\mathrm{r}=0.33 ; \mathrm{p}<0.10)$. Therefore, relatively high rates of $\mathrm{PO}_{4}^{-}$release that were measured during the warmer months are likely due in part to increased rates of decomposition.

Surprisingly, $\mathrm{PO}_{4}^{-}$flux did not show a relationship with DO concentration, although other experiments in Mobile Bay show that $\mathrm{PO}_{4}^{-}$fluxes may be strongly affected by DO concentration (Fernandez 1995). How- 
ever, Fernandez (1995) also found that the magnitude of $\mathrm{PO}_{4}^{-}$release under hypoxic conditions is positively related to the amount of time the sediments have been exposed to low DO. This suggests that, upon exposure to low-oxygen bottom-waters, the sediments must first become further reduced before desorption of $\mathrm{PO}_{4}{ }^{-}$from particulates may occur. Sediment resuspension in this shallow system may also have complicated the patterns of sorption/desorption processes by reoxidizing sediments and disrupting pore water concentrations gradients, making relationships with DO concentration difficult to decipher (Sondergaard et al. 1992, Vidal 1994).

\section{Interannual variability in fluxes}

Interannual differences in fluxes were also evident (Table 5). Ammonium, $\mathrm{PO}_{4}^{-}, \mathrm{DSi}$, and DIN fluxes (summed $\mathrm{NH}_{4}{ }^{+}, \mathrm{NO}_{3}{ }^{-}$and $\mathrm{NO}_{2}{ }^{-}$fluxes) were higher in 1993 while $\mathrm{NO}_{2}^{-}$and $\mathrm{NO}_{3}^{-}$fluxes were higher in 1994. As a result of the high degree of intra-annual variability, statistically significant interannual differences were observed only for $\mathrm{NO}_{3}^{-}$(based on Student's $t$ test). Nonetheless, these data suggest the potential for important interannual differences in fluxes, particularly for the nitrogen species. This is most likely the result of oxygen-dependent changes in relationships between overall DIN regeneration, nitrification, and denitrification.

Flux ratios were calculated and compared with those expected from the simple decomposition of healthy phytoplanktonic material in an attempt to quantify

Table 5. Annually averaged means and standard deviations (SD) of selected variables. The variable DIN flux is the mean and standard deviation of monthly summed $\mathrm{NH}_{4}{ }^{+}, \mathrm{NO}_{3}{ }^{-}$, and $\mathrm{NO}_{2}{ }_{2}^{-}$fluxes. Ratios are the mean and $\mathrm{SD}$ of results of division. of monthly fluxes. For O:N ratios, SOC was converted to $\mu \mathrm{mol}$ $\mathrm{m}^{-2} \mathrm{~h}^{-1}$, and multiplied by 2 to obtain the amount of $O$ (rather than $\mathrm{O}_{2}$, shown in SOC measurements) consumed

\begin{tabular}{|c|c|c|c|c|}
\hline & \multicolumn{2}{|c|}{1993} & \multicolumn{2}{|c|}{1994} \\
\hline & Mean & SD & Mean & $\mathrm{SD}$ \\
\hline $\mathrm{SOC}$ & 0.58 & 0.37 & 0.54 & 0.20 \\
\hline $\mathrm{NH}_{4}{ }^{+}$flux & 69.97 & 77.4 & 38.49 & 51.4 \\
\hline $\mathrm{NO}_{3}^{-}$flux & 8.92 & 14.67 & 19.53 & 19.98 \\
\hline $\mathrm{NO}_{2}$ flux & 1.06 & 2.83 & 1.86 & 3.45 \\
\hline DIN flux & 82.61 & 79.85 & 59.88 & 50.17 \\
\hline $\mathrm{PO}_{4}^{-}$flux & 4.37 & 5.95 & 3.47 & 2.84 \\
\hline DSiflux & 132.70 & 120.9 & 104.36 & 66.45 \\
\hline \multicolumn{5}{|l|}{ Ratios: } \\
\hline $\mathrm{O}: \mathrm{NH}_{4}{ }^{+}$ & 55.04 & 60.62 & 98.99 & 116.4 \\
\hline O:DIN & 40.72 & 43.52 & 26.34 & 15.85 \\
\hline $\mathrm{NH}_{4}^{+}: \mathrm{P}$ & 20.51 & 23.26 & 22.04 & 19.72 \\
\hline DIN:P & 23.16 & 23.65 & 29.67 & 28.67 \\
\hline
\end{tabular}

these relationships. Redfield (1934) found that such decomposition yields an $\mathrm{O}: \mathrm{N}\left(\mathrm{NH}_{4}{ }^{+}\right)$molar ratio of 13.25, or 17.25 if all regenerated nitrogen is converted to $\mathrm{NO}_{3}^{-}$, and an $\mathrm{N}\left(\mathrm{NH}_{4}{ }^{+}\right): \mathrm{P}\left(\mathrm{PO}_{4}^{-}\right)$ratio of 16 . However, sediment biogeochemical processes can alter the ratio at which these nutrients are released. For example, O:DIN flux ratios that are substantially closer to Redfield than $\mathrm{O}: \mathrm{NH}_{4}{ }^{+}$flux ratios for the same data indicate that rates of nitrification were considerable. Similarly, small differences in O:DIN and $\mathrm{O}: \mathrm{NH}_{4}{ }^{+}$ratios suggest that very little of the regenerated nitrogen was nitrified, or - if $\mathrm{O}: \mathrm{NH}_{4}{ }^{+}$ratios are substantially different from Redfield proportions - that much that was nitrified was subsequently denitrified before release from the sediments (Nixon 1981, Banta et al. 1995)

For this study, O: $\mathrm{NH}_{4}{ }^{+}$and O:DIN flux ratios (Table 5) were quite different between 1993 and 1994, indicating that processes influencing nitrogen fluxes were operating to different degrees between the $2 \mathrm{yr}$. Specifically, the greatest difference between $\mathrm{O}: \mathrm{NH}_{4}{ }^{+}$ and O:DIN ratios within any 1 yr came in 1994, suggesting that the proportion of regenerated nitrogen that was nitrified was higher in 1994 than in 1993.

There is also evidence that anaerobic decomposition was occurring. There were 4 mo (late August and September 1993, June and August 1994) when the O:DIN ratio was less than 17.25 , and indeed less than the $\mathrm{O}: \mathrm{NH}_{4}{ }^{+}$ratio of 13.25 (Fig. 8) suggesting that rates of sulfate reduction may have been high at these times, causing more nitrogen to be produced by the sediments than would be expected based on the amount of oxygen that was consumed. There were also periods when O:DIN ratios were much higher than 17.25, indicating that denitrification was occurring.

As suggested by several other researchers, estimates of denitrification rates can be made based on measured SOC rates (Nixon et al. 1976, Rowe et al. 1977. Nixon 1981, Boynton \& Kemp 1985, Banta et al. 1995). Rates of SOC are converted to units of $\mu \mathrm{mol} O$ $\mathrm{m}^{-2} \mathrm{~h}^{-1}$ and then used to calculate the expected rates of DIN release by the sediments based on the Redfield ratio of 17.25 . The measured rate of DIN release is then subtracted from the expected, and the difference is attributed to that which was lost to denitrification. With the exclusion of the 4 mo when ratios were less than 17.25, averaged monthly estimates of these data suggest that approximately $40 \%$ of the regenerated nitrogen in 1993, and $43 \%$ of that in 1994, was removed from the system via denitrification. This loss by denitrification is in the middle to upper range compared to other estuarine and coastal marine ecosystems (Seitzinger 1987).

However, these estimates should be treated with some caution because of other processes that may contribute to the departure of fluxes from the Redfield 

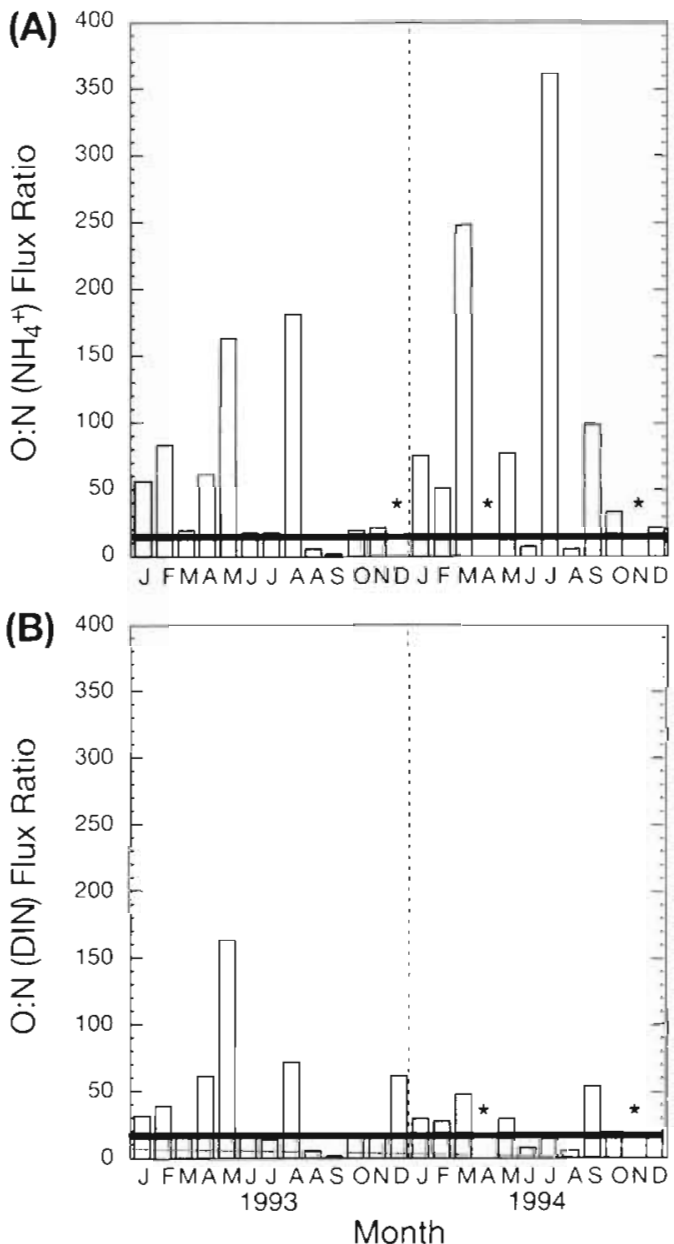

Fig. 8. (A) Average monthly sediment $\mathrm{O}: \mathrm{N}\left(\mathrm{NH}_{4}{ }^{+}\right)$; and (B) average monthly sediment O:N(DIN) flux ratios, from January 1993 to December 1994. Non-interpretable flux ratios due to negative fluxes (uptake by the sediments). The horizontal line indicates the Redfield (1934) ratio

ratio. These may include: (1) differential sequestering of nitrogen by decomposers throughout the year due to their own nitrogen-limitation; (2) uptake of $\mathrm{NO}_{3}{ }^{-}$by the sediments that may also fuel denitrification; (3) decomposition of organic material that itself strongly departs from the Redfield (1934) ratio (Banta et al. 1995); and (4) sulfide oxidation processes that may elevate O:DIN ratios independent of denitrification (Roden \& Tuttle 1992; Roden \& Tuttle 1993a, Roden \& Tuttle 1993b; Jørgensen 1977). The influence of each of these factors is unknown in Mobile Bay, and are potential. sources of error in these estimates of denitrification.

Finally, ratios of DIN:P can suggest the degree to which phosphorus is retained by the sediments. The averages of monthly flux ratios reported in Table 5 show that less phosphorus is released by Mobile Bay sediments than expected on an annual basis, based on the Redfield ratio (N:P ratio higher than the expected 16:1). However, Fig. 9 shows that this ratio varies dramatically from month to month, and that the sediments actually contribute a great deal of phosphorus, relative to nitrogen, to the overlying water during some months of the year. There is no seasonal signal to the variability, however, as has been observed in cooler temperate systems (Fisher et al. 1992, Pennock \& Sharp 1994b). Several factors apparently contribute to this variability, including rates of denitrification and rates of particle adsorption of $\mathrm{PO}_{4}^{-}$, both of which are affected by redox conditions and nutrient concentrations in the sediments and in the overlying water (Pomeroy et al 1965, Patrick \& Khalid 1974, Seitzinger 1988, Boynton et al. 1990). Also, similar to the above description of deviations from the expected O:N ratios, Tezuka (1990) showed that the decomposition of more refractory material caused strong deviations from the Redfield ratio due to differential sequestering of $\mathrm{PO}_{4}^{-}$by microbial populations.

In light of the high estimated $\mathrm{O}: \mathrm{N}$ flux ratios in Mobile Bay, it is interesting that DIN:P ratios are so high. Based on these data, 2 processes-denitrification and phosphate sorption mechanisms - are working in Mobile Bay to remove both nitrogen and phosphorus from the system. If this is the case, Mobile Bay sediments are acting as a buffer against the effects of eutrophication by reducing the supply of regenerated nutrients to phytoplankton.

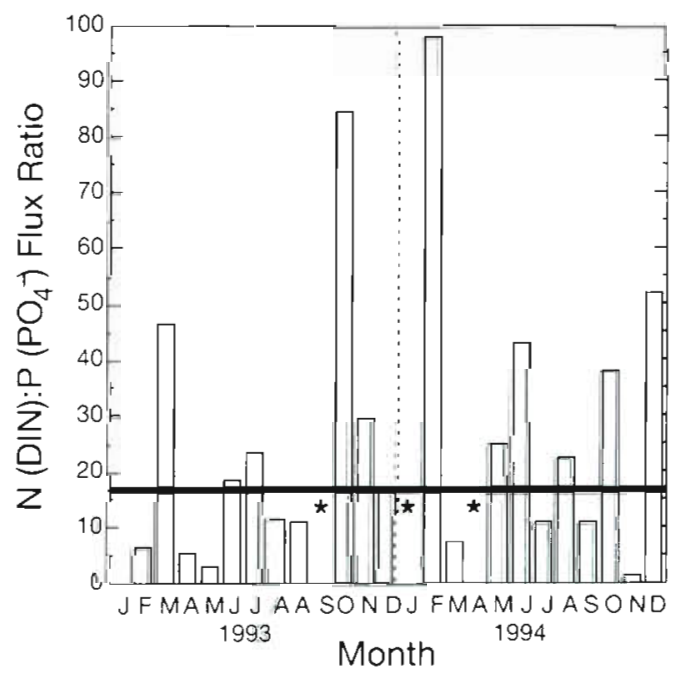

Fig. 9. Average monthly sediment dissolved inorganic nitrogen (DIN): phosphate flux ratios [N(DIN): $\left.\mathrm{P}\left(\mathrm{PO}_{4}^{-}\right)\right]$, from January 1993 to December 1994 . Non-interpretable flux ratios due to negative fluxes (uptake by the sediments). The horizontal line indicates the Redfield (1934) ratio 


\section{Sediment nutrient fluxes and phytoplankton production}

To estimate the contribution by sediment nutrient releases to phytoplankton nutrient demand, calculations of phytoplankton nitrogen and phosphorus demand were made based on monthly measured rates of primary production and compared to monthly measured rates of DIN and $\mathrm{PO}_{4}^{-}$release. Rates of areal primary production (mgC m $\mathrm{m}^{-2} \mathrm{~d}^{-1}$ ), measured from July 1993 through November 1994, were converted to nutrient demand ( $\mu \mathrm{mol} \mathrm{m}^{-2} \mathrm{~h}^{-1}$ ) using Redfield's (1934) C:N:P ratio of 106:16:1 for healthy phytoplankton. The average of these 17 mo of data show that the sediments supplied overlying waters with about $36 \%$ of the nitrogen and about $23 \%$ of the phosphorus required by phytoplankton. This is not a particularly high value compared to estimates made for other systems (Fisher et al. 1982). However, the percent contribution varied a great deal on a monthly basis ( $\% \mathrm{~N}$ contribution ranged from 0 to $94 ; \% \mathrm{P}$ contribution ranged from 0 to 83 ; Fig. 10). In general, there were no seasonal patterns of percent contribution by the
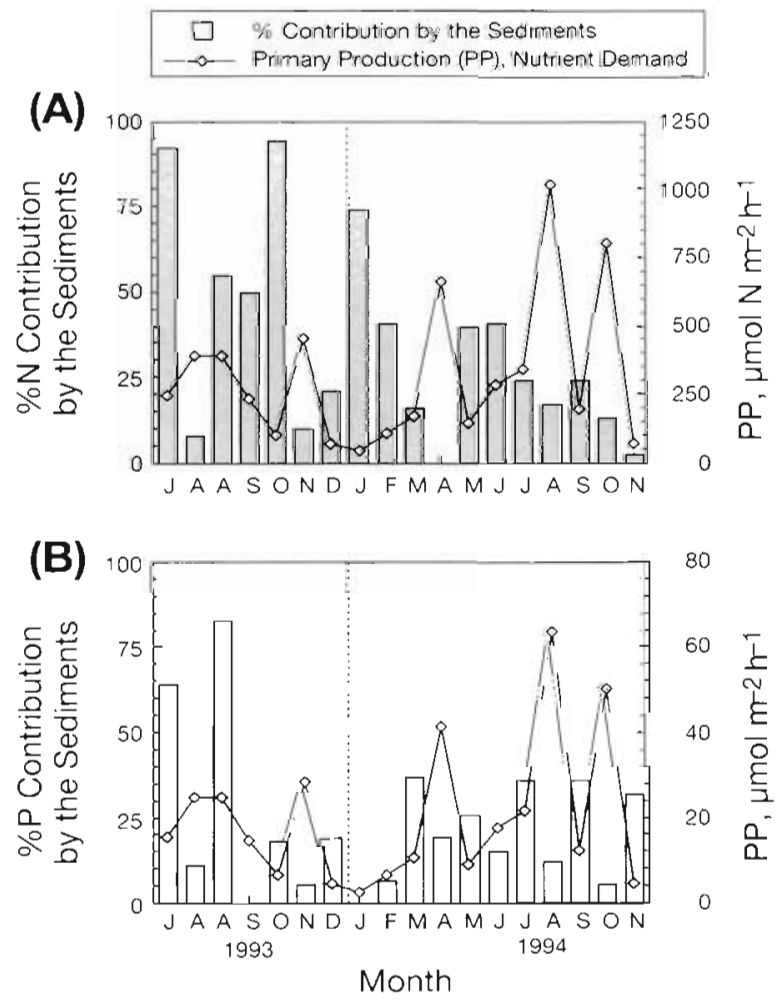

Fig. 10. Calculated monthly demand of $(A)$ nitrogen and (B) phosphorous by phytoplankton (line graphs), overlying the percent contribution to that demand by sediment release of DIN and $\mathrm{PO}_{4}^{-}$(bar graphs), for July 1993 to December 1994. Nitrogen and phosphorus demands by phytoplankton were determined by converting the measured rate of primary production $\left(\mathrm{gC} \mathrm{m}^{-2}\right.$ $\mathrm{d}^{-1}$ ) to demand using the Redfield (1934) C:N:P ratio for healthy phytoplankton sediments, due in part to the fact that primary production did not show a strong seasonal pattern. Data from 1993 show that the sediments have the potential to supply the majority of nutrients required by phytoplankton when primary production rates are relatively low. However, when production rates are high, as in August of 1994, even very high rates of nitrogen and phosphorus release by the sediments supply only a small amount of that required by phytoplankton.

It would appear that factors other than nutrient supply by the sediments allow for the very high rates of primary production observed in summer and fall 1994. Nutrients regenerated at the sediment-water interface more likely serve to maintain algal biomass and production when nutrient supply from allochthonous sources is low, as was the case in 1993 when river flow was very low all summer In 1994 river flow remained higher than in 1993 throughout the summer (Fig. 3) injecting 'new' nutrients into the system that supported a greater percentage of primary production than in summer 1993.

\section{Comparison of flux characteristics with other systems}

In Chesapeake Bay, Cowan \& Boynton (1996) found a highly significant regression relationship between the average amount of total chl $a$ in the top $1 \mathrm{~cm}$ of sediment (an indicator of labile organic matter availability) and the average warm season nutrient flux $\left(\mathrm{NH}_{4}^{+}, \mathrm{PO}_{4}^{-}, \mathrm{DSi}\right)$ from the sediments, if these 2 parameters were lagged in time. In that analysis, sediment chl a was averaged between Day 80 and 220 of the year, and nutrient flux was averaged between Day 120 and 220 (when greatest rates of nutrient release were measured) to account for the apparent delay in decomposition of deposited organic material until temperatures increase in the late spring (Boynton et al. 1991). Despite strong differences in water-column characteristics and sediment nutrient fluxes, all stations sampled along the salinity gradient during several years were found to fit the regression model.

Data from Mobile Bay, lagged in the same manner, also fit this regression model very well, even though conditions in Mobile Bay were distinctly different from those at the 3 stations in Chesapeake Bay (Fig. 11). This suggests that sediment chl $a$ is a good predictor of the magnitude of nutrient release from the sediments, although the temporal lag may need to be adjusted from estuary to estuary. Nonetheless, it is intriguing that organic matter availability correlates so well with nutrient release by the sediments over a broad range of estuarine conditions; it is not unlike Nixon's (1981) observation of the strong correlation between primary production and SOC over a wide range of estuarine systems. 

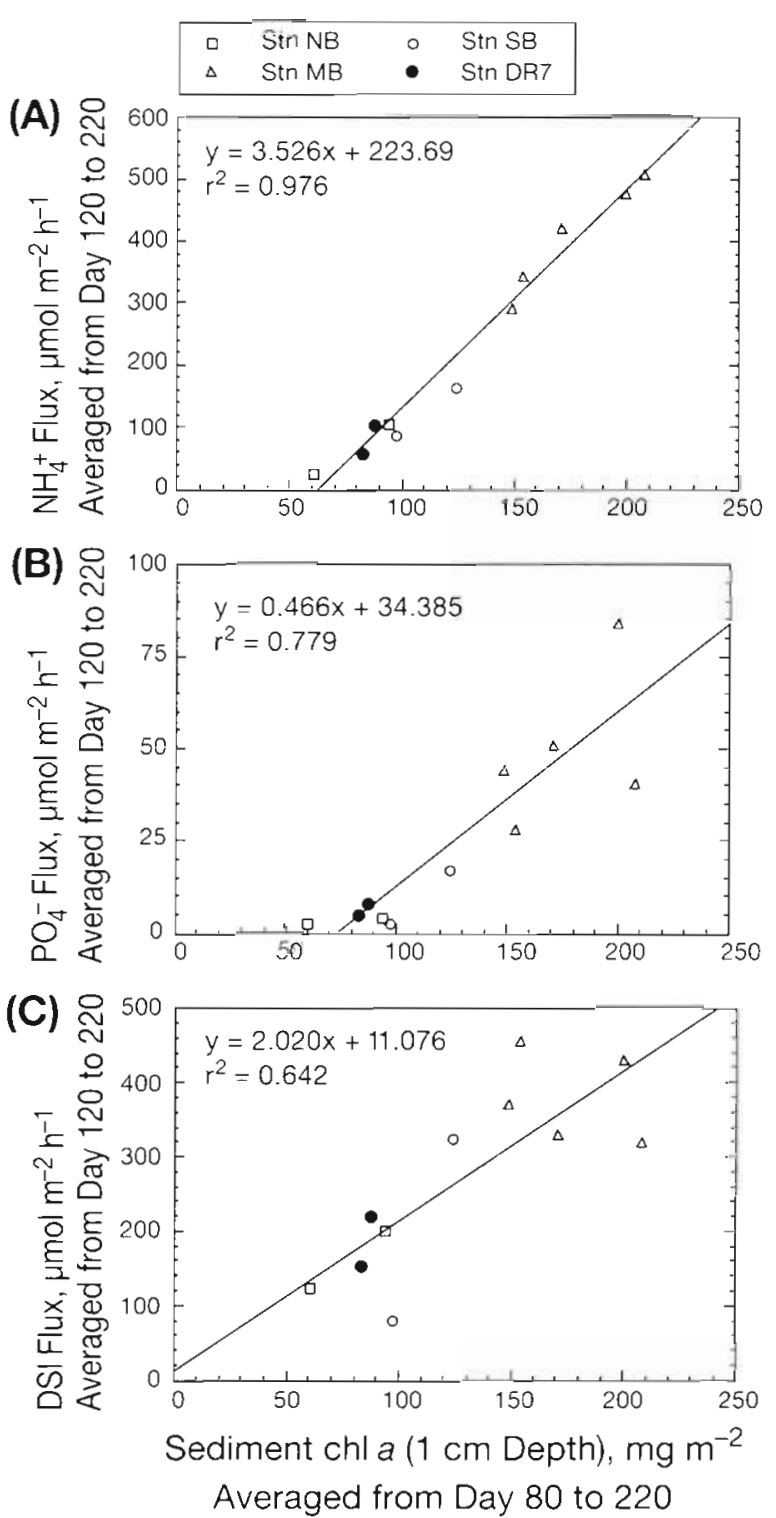

Fig. 11 Simple linear regression plot of average sediment chl a versus (A) average ammonium flux, (B) average phosphate flux, and $(C)$ average dissolved silicate flux for several years at 3 stations in Chesapeake Bay (Stns NB, MB, and SB) and at 1 station in Mobile Bay (Stn DR?). Sediment chl a data (top $1 \mathrm{~cm}$ of sediment) were averaged within each year for the period between Days 80 and 220; sediment nutrient flux data were averaged for the period between Days 120 and 220 of each year. Data from Chesapeake Bay are from Cowan \& Boynton (1996)

However, there are limitations to such relationships. It has been shown by others (Rizzo 1990, Rizzo et al. 1992) that benthic microalgae can greatly reduce nitrogen release rates due to their own nitrogen demand. It should be noted that previously discussed 'light' flux experiments in Mobile Bay suggest that benthic microalgal production is, at best, of only minor importance in these sediments. Another potential limitation of this regression model would occur in regions where nitrification, coupled to denitrification, occurs at very high rates. In this case, even DIN flux would not capture all of the regenerated nitrogen released by the sediments.

Organic matter availability has also been shown to cause seasonal variability in nutrient fluxes. Boynton et al. (1990) found that while temperature and DO concentration influence the magnitude and speciation of fluxes as a result of their influence on microbial processes, these factors alone are not sufficient to describe observed late summer declines in sediment nutrient fluxes in Chesapeake Bay. In fact, fluxes measured in the fall in Chesapeake Bay were often lower than in the spring even though temperatures were higher in the fall, and concentrations of DO were similar during the 2 seasons. They concluded that this pattern was due to the exhaustion of available organic matter in late summer. Similar conclusions were reached by Jensen et al. (1990) from data collected in Aarhus Bight, Denmark. They found that release of $\mathrm{NH}_{4}{ }^{+}$and uptake of $\mathrm{NO}_{3}^{-}$by the sediments increased dramatically immediately following sedimentation of a phytoplankton bloom, and that fluxes returned to low levels just 2 mo after the sedimentation event despite an increase in temperature, presumably because of the exhaustion of available labile organic matter. Others have also attributed seasonal variability of sediment fluxes not simply to temperature and DO concentrations, but also to the availability of labile organic matter (Hammond et al. 1985, Banta et al. 1995).

While the influence of organic matter availability on seasonal variability of fluxes may be supported by data from many estuarine systems where distinct seasonal patterns of phytoplankton biomass occur, it is not supported by data from Mobile Bay. For example, in Chesapeake Bay there is a spring and fall maximum in water-column phytoplankton biomass (Malone et al. 1988); this same pattern also appears in the sediment chl a data (Fig 12; Stns MB and SB). Conversely, Mobile Bay seems to be characterized by more aperiodic events. When there are both sufficient light and nutrient concentrations, phytoplankton blooms may occur, and bloom events are not necessarily limited by cooler temperatures in winter months (Pennock et al. 1995). Further, sediment chl a concentrations do not mimic those in the water-column, but rather show a far more constant pattern throughout the year (Fig. 12). This is presumably because wind-wave resuspension and redistribution of sediments in Mobile Bay rendered the sediment chl a record nearly constant over time. In fact, the sediment chl a record is so constant that if the time lag imposed on Chesapeake Bay data in Fig. 11 were not applied to Mobile Bay data, there would be no difference in the results obtained. Thus, 


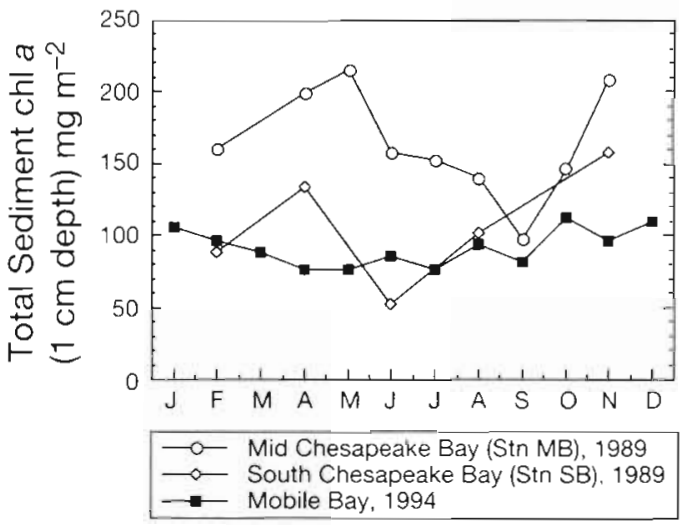

Fig. 12. Patterns of total sediment chl a at the 0 to $1 \mathrm{~cm}$ depth interval at 2 stations in Chesapeake Bay (1989), and at Stn DR7 in Mobile Bay (1994). Chesapeake Bay data are from Cowan \& Boynton (1996)

just as sediment chl a is not always a good indicator of the potential magnitude of sediment nutrient release, it also may not always help to explain temporal variability in fluxes within a system.

\section{CONCLUSIONS}

While Mobile Bay receives high rates of nutrient loading as a result of high rates of freshwater discharge, nutrient concentrations are low compared with other systems because of dilution and low point source discharge rates (Pennock et al. 1995). Consequently, the effects of nutrient enrichment are moderate, as is evidenced by high DSi:DIN ratios, low nutrient and chl a concentrations, and modest rates of primary production. Despite this, Mobile Bay does experience periods of prolonged hypoxia/anoxia as a result of strong salinity stratification events that allow moderate $\mathrm{SOC}$ rates to deplete $\mathrm{DO}$ in isolated bottom waters.

These seemingly contrary characteristics contribute to a rather interesting pattern of sediment nitrogen fluxes, where DO concentration and temperature play large roles in the amount and form of nitrogen that is released by the sediments. When temperature and DO concentrations are high, $\mathrm{NO}_{3}^{-}$release rates may be quite high (among the highest reported) because there is enough oxygen to sustain high rates of nitrification, and because overlying water to porewater $\mathrm{NO}_{3}^{-}$concentration gradients (T. Miller-Way et al. unpubl. data) are generally not high enough to hinder release, as is seen in many more eutrophic systems. When DO concentrations are low, however, Mobile Bay sediments behave similarly to those in more eutrophic estuaries. In this case, sediments release $\mathrm{NH}_{4}^{+}$almost exclusively, and $\mathrm{NO}_{3}^{-}$flux is either near zero or is directed into the sediments. However, even the highest mea- sured rates of release of $\mathrm{NH}_{4}{ }^{+}$are only in the lower to middle range of maximum values reported for other estuaries. This results from the fact that labile organic matter loading to the sediments is rather modest, and thus rates of decomposition are only moderate compared with more eutrophic systems.

Surprisingly, $\mathrm{PO}_{4}{ }^{-}$flux did not relate to $\mathrm{DO}$ concentration in this study. This may be due, in part, to a sediment response to low bottom-water DO concentrations (Fernandez 1995) that is slower than the rate of change of $\mathrm{DO}$ in the bottom-waters. This high variability in bottom-water DO is caused by frequent vertical mixing events which reaerate bottom-waters, as well as disrupt sediment pore water concentration gradients. These constantly changing physical and chemical dynamics also lead to pulsing of nitrogen and phosphorus fluxes at ratios that vary independent of seasonal cycles, unlike what has been shown in many cooler temperate estuaries.

Acknowledgements. We acknowledge the following colleagues for their assistance in completing this work: Mike Dardeau, Alan Gunter, Felix Fernandez, Russell Wilson, and Rodney Collier for help in the field; Drs Tina Miller-Way, Judy Stout, Will Schroeder, and Larry Tate for helpful comments on the manuscript. Comments from 2 anonymous reviewers were also very helpful. This manuscript is part of a thesis submitted to the University of South Alabama in partial fulfillment of the requirements of the degree of Master of Science. This work was supported by the National Science Foundation Experimental Program to Stimulate Competitive Research (Grant No. R11-8996152). This is Dauphin Island Sea Lab contribution no. 277, University of Alabama Aquatic Biology Program contribution no. 230, and Center for Environmental and Estuarine Studies of the University of Maryland contribution no. 2747.

\section{LITERATURE CITHD}

Aller RC, Benninger LK (1981) Spatıal and temporal patterns of dissolved ammonium, manganese, and silica fluxes from bottom sediments of Long Island Sound, USA. J Mar Res 39:295-314

Alpkem Manual (1988) Alpkem Corporation, Clakamas, OR

Banta GT, Giblin AE, Hobbie JE, Tucker J (1995) Benthic respiratıon and nitrogen release in Buzzards Bay, Massachusetts. J Mar Res 53:107-135

Boynton WR. Kemp WM (1985) Nutrient regeneration and oxygen consumption bysediments along an estuarine salinity gradient. Mar Ecol Prog Ser 23:45-55

Boynton WR, Kemp WM, Barnes JM, Cowan JLW, Stammerjohn SE, Matteson LL, Rohland FM, Marvin M, Garber JH (1990) Long-term characteristics and trends of benthic oxygen and nutrient fluxes in the Maryland portion of the Chesapeake Bay. In: Mihursky JH (ed) New perspectives in the Chesapeake system: a research and management partnership. Chesapeake Research Consortium, Baltimore, MD, p 339-354

Boynton WR, Kemp WM, Barnes JM, Matteson LL, Watts JL, Stammerjohn SE, Jasinski DA, Rohland FM (1991) Maryland Chesapeake Bay water quality monitoring program; ecosystem processes component level 1 interpretive report 
no. 8. (interpretive no. \{UMCEES\} CBL ref. no. 91-110) Chesapeake Biological Laboratory, Solomons, $\mathrm{MD}$

Boynton WR, Kemp WM, Osbourn CG (1980) Nutrient fluxes across the sediment water interface in the turbid zone of a coastal plain estuary. In: Kennedy VS (ed) Estuarine perspectives. Academic Press, New York, p 93-109

Caraco NF, Cole JJ, Likens GE (1989) Evidence for sulphatecontrolled phosphorousrelease from sediments of aquatic systems. Nature 341:316-318

Carpenter JH (1964) The accuracy of the Winkler method for dissolved oxygen. Limnol Oceanogr 10:135-140

Conley DJ, Malone TC (1992) Annual cycle of dissolved silicate in Chesapeake Bay: implications for the production and fate of phytoplankton biomass. Mar Ecol Prog Ser 81: $121-128$

Cowan JLW, Boynton WR (1996) sediment water oxygen and nutrient exchanges along the longitudinal axis of Chesapeake Bay: seasonal patterns, controlling factors and ecological significance. Estuaries 19:562-580

Dardeau MR, Shipp RL, Wallace RK (1990) Faunal components. In: Stout JP (ed) Estuary of the month seminar series. National Oceanic and Atmosphenc Administration, Washington, DC, p 89-114

Davies JM (1975) Energy flow through the benthos in a Scottish sea loch. Mar Biol 31:353-362

Elderfield H, Luedtke N. McCaffrey RJ, Bender M (1981) Benthic flux studies in Narraganselt Bay. Am J Sci 281. $768-787$

Eppley RW, Sharp JH (1975) Photosynthetic measurements in the central north Pacific: the dark loss of carbon in $24 \mathrm{~h}$ incubations. Limnol Oceanogr 20:981-987

Fernandez F (1995) Nitrogen and phosphorous fluxes across the sediment water interface during summer oxic and hypoxic/anoxic penods in Moblle Bay, Alabama. MSc thesis, University of South Alabama

Fisher TR, Carlson PR, Barber RT (1982) Sediment nutrient regeneration in three North Carolina estuaries. Estuar Codst Shelf Sci 14:101-116

Fisher TR, Peele ER, Ammerman JW, Harding JLW (1992) Nutrient limitation of phytoplankton in Chesapeake Bay. Mar Ecol. Prog Ser 82:51-63

Flint RW, Kamykowski D (1984) Benthic nutrient regeneration in south Texas coastal waters. Estuar Coast Shelf Sci 18: $221-230$

Forja JM, Blasco J, Gomez-Parra A (1994) Spatial and seasonal variation of in situ benthic fluxes in the Bay of Cadız (south-west Spain). Estuar Coast Shelf Sci 39:127-141

Hammond DE, Fuller C, Harmon D, Hartman B, Korsec M, Miller LG, Rea R, Warren S, Berelson W. Hagar SW (1985) Benthic fluxes in San Francisco Bay. Hydrobiologia 129: $69-90$

Hargrave BT (1969) Similarity of oxygen uptake by benthic communities. Limnol Oceanogr 14:801-805

Hargrave BT (1973) Coupling carbon flow through some pelagic and benthic communities. J Fish Res Bd Can 30 : $1317-1326$

Henriksen K, Hansen JI, Blackburn TH (1980) The influence of benthic infauna on exchange rates of inorganic nitrogen between sediment and water. Ophelia 1:249-256

Henriksen K, Kemp WM (1988) Nitrification in estuarine and coastal marine sediment. In: Blackburn TH, Sørensen J (eds) Nitrogen cycling in coastal marine environments. J Wiley \& Sons, New York, p 207-249

Henriksen K, Rasmussen MB, Jensen A (1983) Effect of bioturbation on microbial nitrogen transformations in the sediment and fluxes of ammonium and nitrate to the overlying water. Ecol Bull 35:193-205
Jensen $\mathrm{MH}$, Lomstein E, Sorensen $\mathrm{J}$ (1990) Benthic $\mathrm{NH}_{4}^{*}$ and $\mathrm{NO}_{3}$ - flux following sedimentation of a spring phytoplankton bloom in Aarhus Bight, Denmark. Mar Ecol Prog Ser $61: 87-96$

Jorgensen BB (1977) The sulfur cycle of a coastal marine sed 1 ment (Limfjorden, Denmark). Limnol Oceanogr 22:814-832

Kamatani A (1982) Dissolution rates of silica from diatoms decomposing at various temperatures. Mar Biol 68:91-96

Kelly JR, Nixon SW (1984) Experimental studies of the effect of organic deposition on the metabolism of a coastal marine bottom community. Mar Ecol Prog Ser 17:157-169

Kemp WM, Sampou P, Caffrey J, Mayer M, Henriksen K, Boynton WR (1990) Ammonium recycling versus denitrification in Chesapeake Bay sediments. Limnol Oceanogr $35: 1545-1563$

Kemp WM, Sampou PA, Garber J, Tuttle J, Boynton WR (1992) Seasonal depletion of oxygen from bottom waters of Chesapeake Bay: roles of benthic and planktonic respiration and physical exchange processes. Mar Ecol Prog Ser 85:137-152

KJump JV, Martens CS (1981) Biogeochemical cycling in an organic rich coastal marine basin. Il. Nutrient sediment water exchange processes. Geochim et Cosmochim Acta 45:101-121

Malone TC, Crocker LH, Pike SE, Wendler BW (1988) Influences of river flow on the dynamics of phytoplankton production in a partially stratified estuary. Mar Ecol Prog Ser 48:235-249

May EB (1973) Extensive oxygen depletion in Mobile Bay, Alabama. Limnol Oceanogr 18:353-366

Morisawa M (1968) Streams, their dynamics and morphology. McGraw-Hill, New York

Nedwell DB, Hall SE, Anderson A, Hagstrom AF, Lindstrom EB (1983) Seasonal changes in the distribution and exchange of inorganic nitrogen between sediment and water in the northern Baltic (Gulf of Bothnia). Estuar Coast Shelf Sci 17:169-179

Nixon SW (1981) Remineralization and nutrient cycling in coastal marine ecosystems. In: Neilson BJ, Cronin LE (eds) Estuaries and nutrients. Humana, New York, p 111-138

Nixon SW, Oviatt CA, Hale SS (1976) Nitrogen regeneration and the metabolism of coastal marine bottom communj. ties. In: Anderson JM. MacFadyen A (eds) The role of terrestrial and aquatic organisms in decomposition processes. Blackwell, London, p 269-283

Nixon SW. Pilson MQ (1983) Nitrogen in estuarine and coastal marine ecosystems. In: Carpenter EJ, Capone DG (eds) Nitrogen in the marne environment. Academic Press, New York, p 565-648

NOAA/EPA (1989) Strategic assessment of near coastal waters: susceptibility and status of Gulf of Mexico estuaries to nutrient discharges. Strategic Assessment Branch, NOS/NOAA, Rockville, MD

Officer CB, Ryther JH (1980) The possible importance of sillcon in manne eutrophicatıon. Mar Ecol Prog Ser 3:83-91

Paasche E (1980) Silıcon. In: Morris I (ed) The physiological ecology of phytoplankton. Studies in ecology. University of Callfornia Press, Berkeley, 259-284

Parsons TR, Maita Y, Lalli CM (1984) A manual of chermical and biological methods for seawater analysis. Pergamon Press, Elmsford, NY

Patnck WH Jr, Khalid RA (1974) Phosphate release and sorption by soils and sediments: effect of aerobic and anaerobic conditions. Science 186:53-55

Pennock JR, Sharp JH (1.986) Phytoplankton production in the Delaware Estuary: temporal and spatial variability. Mar Ecol Prog Ser 34:143-155 
Pennock JR, Fernandez F, Schroeder WW (1994a) Mobile Bay data report. Marine Environmental Sciences Consortium, Dauphin Island Sea Lab Technical Report No. 94-001

Pennock JR. Sharp JH (1994b) Temporal alteration between light and nutrient limitation of phytoplankton production in a coastal plain estuary. Mar Ecol Prog Ser 111:275-288

Pennock JR, Sharp JH, Schroeder WW (1995) What controls the expression of estuarine eutrophıcation? In: Dyer KR, Orth RJ (eds) Changes in fluxes in estuaries. Olsen \& Olsen, Fredensborg, p 139-146

Pomeroy LR, Smith EE, Grant CM (1965) The exchange of phosphate between estuarine water and sedmments. Lımnol Oceanogr 10:167-172

Propp MV. Tarasoff VG, Cherbadgi II, Lootzik NV (1980) Benthic-pelagic oxygen and nutrient exchange in a coastal region of the Sea of Japan. In: Tenore KR, Coull BC (eds) Marine benthic dynamics. University of South Carolina Press, Columbia, p 265-284

Redfield AC (1934) On the proportions of organic derivatives in seawater and their relation to the composition of the plankton. In: James Johnstone memorial volume. University Press, Liverpool, p 176-192

Rhoades DC, McCall PL, Yingst JY (1978) Disturbance and production on the estuarine seafloor Am Sci 66:577-586

Rizzo WM (1990) Nutrient exchanges between the water column and a subtidal benthic microalgal community. Estuaries 13:219-226

Rizzo WM, Lackey GJ, Christian RR (1992) Significance of euphotic, subtidal sedıments to oxygen and nutrient cycling in a temperate estuary. Mar Ecol Prog Ser 86: $51-61$

Roden EE, Tuttle JH (1992) Sulfide release from estuarine sediments underlying anoxic bottom water. Limnol Oceanogr $37: 725-738$

Roden EE, Tuttle JH (1993a) Inorganic sulfur cycling in mid and lower Chesapeake Bay sediments. Mar Ecol Prog Ser 93:101-118

Roden EE, Tuttle JH (1993b) Inorganic sulfur turnover in oligohaline estuarine sedıments. Biogeochemistry 22:81-105

Rowe GT, Clifford CH, Smith KL Jr (1977) Nutrient regeneration in sediments off Cape Blanc, Spanish Sahara. Deep Sea Res 24:57-63

Schroeder WW (1977) Sea truth and environmental character-

This article was submitted to the editor 1zation studies of Mobile Bay, Alabama, utilizing ERTS-1, data collection plattorms. Remote Sens Environ 6:27-43

Schroeder WW. Wiseman WJ Jr (1986) Low-frequency shelfestuarine exchange processes on the northern Gulf of Mexico, with emphasis on Mobile Bay. In: Wolfe DA (ed) Estuarine varıability. Academic Press, New York, p 355-361

Seltzinger S (1987) Nitrogen blogeochemistry in an unpolluted estuary: the importance of benthic denitrification. Mar Ecol Prog Ser 41:177-186

Seitzinger S (1988) Denitrification in freshwater and coastal marne ecosystems: ecological and geochemical significance. Limnol Oceanogr 33:702-724

Sharp JH (1974) Improved analysıs for 'particulate' organic carbon and nitrogen from seawater. Limnol Oceanogr 19: $984-989$

Sondergaard M, Kristensen P. Jeppsen E (1992) Phosphorous release from resuspended sediment in the shallow and wind-exposed Lake Arreso, Denmark. Hydrobiologia 228: 91-99

Statsoft (1991) Statistica/Mac, version 3.0b. Statsoft, Inc, Tulsa, OK

Stumpf RP (1991) Observation of suspended sediments in Mobile Bay, Alabama from satellite. In: Coastal sediments specialty conference. ASCE, Seattle, WA

Sundbäck K, Enoksson V, Granneli W, Petersson K (1991) Influence of sublittoral microphytobenthos on the oxygen and nutrient flux between sediment and water: a laboratory continuous-flow study. Mar Ecol Prog Ser 74:263-279

Sundby B, Gobell C, Silverberg N, Mucci A (1992) The phosphorous cycle in coastal marine sediments. Limnol Oceanogr 37:1129-1145

Teague KG, Madden CJ. Day JW Jr (1988) sediment water oxygen and nutrient fluxes in a river-dominated estuary. Estuaries 11:1-9

Tezuka Y (1990) Bacterial regeneration of ammonium and phosphate as affected by the C:N:P ratio of organic substrate. Microb Ecol 19:227-238

van Duyl FC, van Raaphorst W, Kop AJ (1993) Benthic bacterial production and nutrient seriment water exchange in sandy North Sea sediments. Mar Ecol Prog Ser 100:85-95

Vidal M (1994) Phosphate dynamics tied to sedıment disturbances in Alfacs Bay (NW Mediterranean) Mar Ecol Prog Ser 110:211-221

Manuscript first received: December 18, 1995 Revised version accepted: June 6, 1996 